\title{
Anti-Inflammatory Role of Natural Polyphenols and Their Degradation Products
}

\author{
Balázs Veres \\ University of Pécs \\ Hungary
}

\section{Introduction}

A tight regulation of the immune/inflammatory system is crucial for maintaining the balance between protective and tissue-damaging responses. Systemic inflammatory response syndrome (SIRS) and sepsis are characterized by a loss of control over inflammatory responses, which can be provoked by a variety of causative agents and severe clinical insults. Sepsis is the most common cause of death in intensive care units worldwide and despite the extensive research we do not fully understand the cellular and molecular mechanisms that are involved in triggering and propagation of septic injury. A number of different approaches have been investigated to try to treat and/or prevent septic shock associated with infections caused by Gram-negative bacteria. Antibiotics constitute a necessary part of the treatment of sepsis, but antibiotics alone, even used optimally, are not sufficient to dramatically reduce the mortality of septic patient, because antibiotics cannot control the complex systemic inflammation and dysregulated host responses. For this reason, considerable efforts have been expended in developing non-antibiotic forms of treatment.

A wide variety of dietary plants including grains, berries, legumes, tea, beer, grape/wine, olive oil, chocolate/cocoa, coffee, walnuts, peanuts, spices, fruits, vegetables etc. contain polyphenols (Bravo, 1998). Polyphenols, with 8000 structural variants, are characterized by the presence of aromatic rings bearing one or more hydroxyl moieties, which have a pivotal role in mediating of its antioxidant properties. As antioxidants, polyphenols are normally produced by plants for their antibiotic and antifungal features (Leiro et al., 2004). Polyphenols are generally divided into six major groups: hydroxybenzoic acids, phenolic alcohols, hydroxycinnamic acids, lignans, flavonoids and stilbenes (e.g. resveratrol) (D'Archivio et al., 2007). Recently, a number of natural products or ingredients of traditional medicines and healthy foods such as resveratrol, curcumin, and catechins were extensively investigated and subjected to clinical trials as anti-inflammatory agents (Hatcher et al., 2008). Although the knowledge of absorption, bioavailability and metabolism of polyphenols is not entirely known, it appears that some polyphenols are bioactive and are absorbed in their native or modified form. After the metabolization of polyphenols by the microflora of the intestines, their absorbed forms may be detected in plasma in nanomolar concentration (Rahman et al., 2006).

The active components of dietary phytochemicals (e.g. curcumin, resveratrol, capsaicin, catechins, vitamins, beta carotene and dietary fiber) are believed to suppress the 
inflammatory processes, moderate cell signaling pathways, proliferation, apoptosis, redox balance and most often appear to be protective against cancer, neurodegenerative disorders and cardiovascular diseases (Aggarwal \& Shishodia, 2006; Rahman et al., 2006). Polyphenols can exert their anti-inflammatorical properties at multiple levels, through the modulation of MAPK, Akt and NF-kB signaling pathways, inhibition the production of inflammatory cytokines and chemokines, suppressing the activity of COX and iNOS and decreasing the production of ROS/RNS. MAPKs which play critical roles in inflammation are inhibited by catechins in macrophages (Ichikawa et al., 2004). Other dietary phytochemicals, namely curcumin, resveratrol and green tea polyphenols have been shown to modulate the MAP kinases and it was dependent on cell type and on the polyphenol used. Akt plays crucial roles in mammalian cell survival signalling and has been shown to be activated in various cancers (Chang et al., 2003). Activated Akt promotes cell survival by activating NF-kB signalling pathway (Romashkova \& Makarov, 1999). Several phytochemicals including genistein (Li \& Sarkar, 2002), curcuminoids (Aggarwal et al., 2006) and catechins (Tang et al., 2003) are known to suppress the activation of Akt, in this way inhibit cancer cell growth. Almost all cell types, when exposed to TNF-a, LPS or other stimuli, activate NF-kB and AP1 transcription factors, leading to the expression of inflammatory genes, such as COX-2, iNOS, cell adhesion molecules, inflammatory cytokines and chemokines. Thus, all the dietary agents that can suppress these transcription factors have the potential of inhibiting the expression of COX-2, iNOS, cell adhesion molecules, TNF- $\alpha$ and interleukins. Several dietary components including green tea catechins (Gerhäuser et al., 2003), curcumin (Plummer et al., 1999), and resveratrol (Subbaramaiah et al., 1998) have been shown to suppress COX-2 and in this way to decrease the production of reactive oxygen species. iNOS, which is responsible for the release of free radical nitric oxide, was suppressed by several phytochemicals and dietary agents in RAW 264.7 macrophage cell line, stimulated with LPS and interferon- $\gamma$ (IFN- $\gamma$ ) (Kim et al., 1998). Other sources of the antioxidant properties of polyphenols is their free radicals scavenger features, which is based on their structure (Joe \& Lokesh, 1994, Babu \& Liu, 2008). Furthermore, several polyphenols suppress lipid peroxidation through to maintain the cellular status of antioxidant enzymes like superoxide dismutase, catalase and glutathione peroxidase (Labinskyy et al., 2006; Reddy \& Lokesh, 1992). Due to the NF-kB suppressing effect of polyphenols, some of them (e.g. curcumin, resveratrol, quercetin and green tee polyphenols) have been shown to decrease the expression of chemokines and cytokines (Hidaka et al., 2002, Kowalski et al., 2005).

Recently, the anti-inflammatory properties of natural products or ingredients of traditional medicines and healthy foods were extensively investigated, but the solubility of these compounds is limited. Because of it, it is questionable whether their bioavailability could account for their pharmacological effect. Recent publications show that polyphenols in healthy foods or drinks such as chocolate, red wine, or beer are readily metabolized to phenolic acids and aldehydes by the microflora of the intestines, raising the possibility that these metabolites, rather than the original natural products or food ingredients, are responsible for their anti-inflammatory properties (Gonthier et al., 2003; Rios et al., 2003).

In the present chapter we summarize our recent knowledge about the effect of natural polyphenols in systemic inflammatory conditions focusing on their metabolites and degradation products. These compounds could represent new potential clinical approaches in the therapeutic intervention of severe sepsis and septic shock. 


\section{Polyphenols}

A wide variety of dietary plants including grains, fruits, vegetables, cereals, olive, dry legumes, chocolate and beverages, such as tea, coffee and red wine contain polyphenols (Bravo, 1998). Polyphenols, with 8000 structural variants, are characterized by the presence of aromatic rings bearing one or more hydroxyl moieties, which have a pivotal role in mediating of its antioxidant properties. As antioxidants, polyphenols are normally produced by plants for their antibiotic and antifungal features (Leiro et al., 2004). Although the absorption, bioavailability and metabolism of polyphenols are not entirely known, it appears that some polyphenols are bioactive and are absorbed in their native or modified form. The active components of dietary phytochemicals (e.g. curcumin, resveratrol, capsaicin, catechins, vitamins, beta carotene and dietary fiber) are believed to suppress the inflammatory processes, moderate cell signalling pathways, proliferation, apoptosis, redox balance and most often appear to be protective against cancer, neurodegenerative disorders and cardiovascular diseases (Aggarwal \& Shishodia, 2006, Rahman et al., 2006). Polyphenols can exert their anti-inflammatory properties at multiple levels, through the modulation of mitogen-activated protein kinases (MAPK) signalling pathways (Kong et al., 2000; Wiseman et al., 2001) and NF-kB and AP-1 transcription factors (Manna et al., 2000), inhibition of the production of inflammatory cytokines and chemokines, suppressing the activity of cyclooxygenase (COX) (O'Leary et al., 2004) and inducible nitric oxide synthase (iNOS) (Donnelly et al., 2004) and thereby decreasing the production of reactive oxygen and nitrogen species (ROS/RNS).

In this chapter we discuss the anti-inflammatory properties of some selected polyphenols where the selection is based on the occurrence and importance of these compounds in the literature.

\subsection{Resveratrol}

One of the most investigated and potent polyphenolic compound that is found in highest concentration in the skin of grapes and regulate the inflammation is a stilbene, called resveratrol (3,5,4'-trihydroxy-trans-stilbene) (Figure 1). In the 80's, interest in the possible health benefits of resveratrol in wine was spurred by discussion of the "French paradox" which estimated the state of health of wine drinkers in France. These data suggest that nutritional intake of resveratrol and other polyphenol compounds may contribute to a relatively low incidence of cardiovascular diseases in the Mediterranean population (de Lange, 2007; de Lorgeril et al., 1999; Zern \& Fernandez, 2005).

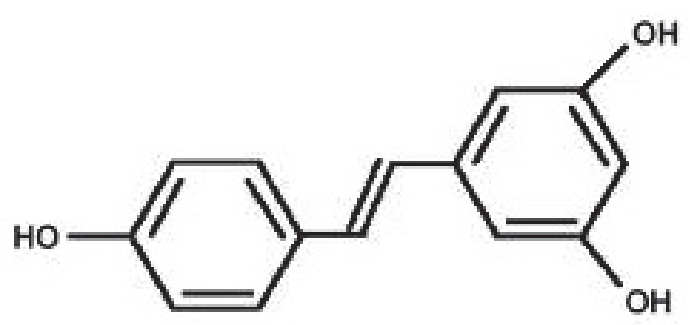

Fig. 1. Structure of resveratrol 
Bioavailability and metabolism of resveratrol have been widely studied and its efficacy depends on its absorption and metabolism. In mice, rats and humans resveratrol has been detected in body fluids (urine, bile, and plasma) as well as in kidneys, stomach, intestine, and liver, following oral administration and this wide tissue targeting suggests an efficient absorption (Boocock et al., 2007; Jang et al., 1997; Vitrac et al., 2003; Wenzel \& Somoza, 2005; Wenzel et al., 2005;).

\subsection{Quercetin}

The flavonoid quercetin (Figure 2) is a potent dietary polyphenol that can exert antiinflammatory, anti-proliferative and anti-oxidative effects (Bischoff, 2008; Boots et al., 2008).<smiles>O=c1c(O)c(-c2ccc(O)c(O)c2)oc2cc(O)cc(O)c12</smiles>

Fig. 2. Structure of quercetin

Foods rich in quercetin include black and green tea, capers, lovage, apples, red grapes and a number of berries (Häkkinen et al., 1999). Dietary quercetin is mostly present as its glycoside form and it is absorbed from the intestinal lumen is mostly converted to conjugated metabolites before entering circulation. A recent study regarding the tissue distribution observed that quercetin concentrated in lungs, testes, kidneys, thymus, heart and liver in rats and in pigs (de Boer et al., 2005). After absorption quercetin can undergo microbial degradation in the colon to phenolic acids and $\mathrm{CO}_{2}$, which is exhaled in the breath.

\subsection{Curcumin}

Curcumin (diferuloylmethane) (Figure 3), an orange-yellow component of turmeric or curry powder, is a polyphenol natural product isolated from the rhizome of the plant Curcuma longa.<smiles>COc1cc(/C=C/C(=O)CC(=O)/C=C/c2ccc(O)c(OC)c2)ccc1O</smiles>

Fig. 3. Structure of curcumin 
Since its first use as a drug in 1937 curcumin's therapeutic potential has been explored in inflammatory diseases, neoplastic disease, cardiovascular and neurodegenerative disease, diabetes, cystic fibrosis and other disorders (Egan et al., 2004; Hsu \& Cheng, 2007; Miriyala et al., 2007; Weisberg et al., 2008). However, curcumin, a highly pleiotropic molecule with an excellent safety profile targeting multiple diseases with strong evidence on the molecular level, could not achieve its optimum therapeutic outcome in past clinical trials, largely due to its low solubility and poor bioavailability. Animal and human studies have shown that curcumin is rapidly metabolized and conjugated in the liver, and then excreted, therefore having limited systemic bioavailability (Cheng et al., 2001; Ireson et al., 2001; Sharma et al., 2004).

\subsection{Epigallocatechin gallate}

Epigallocatechin gallate (EGCG), a principal antioxidant derived from green tea, is one of the most extensively investigated chemopreventive phytochemicals (Figure 4).<smiles>O=C(O[C@H]1Cc2c(O)cc(O)cc2O[C@@H]1c1cc(O)c(O)c(O)c1)c1cc(O)c(O)c(O)c1</smiles>

Fig. 4. Structure of epigallocatechin gallate

Recently, green tea has attracted attention for its health benefits, particularly with respect to its potential for preventing and treating cancer, cardiovascular diseases, inflammatory diseases, and neurodegenerative diseases in humans (Tedeschi et al., 2004; Weisburger \& Chung, 2002; Yang et al., 1998). The metabolism of green tea catechins has been studied in various animals and in human subjects (Lee et al., 1995; Pietta et al., 2008). Orally administrated catechin to humans is absorbed, metabolized, and excreted within 24 hours (Harada et al., 1999) and green tea consumption increased the plasma levels of EGCG in a dose-dependent manner (Nakagawa et al., 1997). Furthermore, Suganuma et al. demonstrated that after direct administration of labelled EGCG into the stomachs radioactivity appeared in a wide range of target organs in mice, including the digestive tract, liver, lung, pancreas, mammary gland and skin, brain, kidney, uterus and ovary and testes (Suganuma et al., 1998).

\subsection{Phenolic acids and aldehydes}

Natural phenolic compounds are secondary plant metabolites and the most abundant antioxidant resources. They are widely distributed in plants and present in considerable amounts in the human diet. Phenolic acids are hydroxylated derivatives of benzoic and 
cinnamic acids. The most common hydroxycinnamic acid derivatives are p-coumaric, caffeic, and ferulic acids which frequently occur in foods as simple esters with quinic acid or glucose. Phenolic acids have received considerable attention due to their various biological activities, including antioxidant, anti-apoptotic and anti-inflammatory capacities (Manach et al., 2004).

Caffeic acid (Figure 5) is a widespread phenolic acid that occurs naturally in many agricultural products such as fruits, vegetables, wine, olive oil, and coffee (Mattila \& Kumpulainen, 2002).

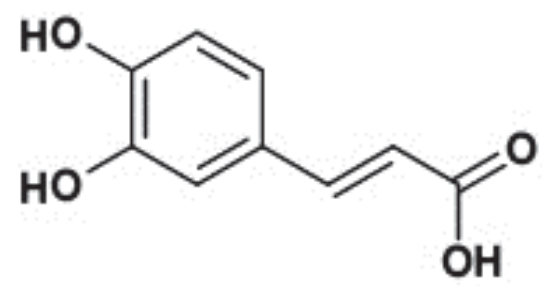

Fig. 5. Structure of caffeic acid

It is a potent antioxidant, metal chelating (Psotova et al., 2003), anti-inflammatory (Chao et al., 2010), free radical scavenger (Gulcin, 2006) and antidiabetic agent. Caffeic acid has been shown to be an inhibitor of the lipoxygenase enzyme and its conjugates such as chlorogenic and caftaric acids were demonstrated to be more powerful antioxidants in a number of different systems (Fukumoto \& Mazza, 2000). Caffeic acid and its derivatives are good substrates of polyphenol oxidases, and under certain conditions may undergo oxidation in plant tissues or products of plant origin (Kerry \& Rice-Evans, 1998).

Ferulic acid (4-hydroxy-3-methoxy cinnamic acid) is a product of the phenylalanine and tyrosine metabolism, and it is produced by the shikimate pathway in plants (Figure 6). It is commonly found in fruits like orange and in vegetables, such as tomato, carrot, sweet corn and rice bran. The wide spectrum of beneficial effects of ferulic acid for human health due to its antibacterial, anti-inflammatory, hepatoprotective, anticancer, antidiabetic, neuroprotective, anti-atherogenic and antioxidant activity (Srinivasan et al., 2007). Partially, because of its antioxidant and anti-inflammatory activity, ferulic acid is considered as a potential therapeutic agent (together with other natural phenolic compounds) against various diseases like cancer, diabetes, cardiovascular dysfunction, inflammatory diseases and neurodegenerative diseases (Soobrattee et al., 2005). Ferulic acid and ferulaldehyde are potential end-products of dietary polyphenol degradation since they were found at a high concentration in human urine after red wine and chocolate consumption (Gonthier, 2003; Rios et al., 2003).

Furthermore, ferulic acid was reported to stay in the blood longer than other antioxidants such as vitamin C, and have higher bioavailability than that of other dietary flavonoids and monophenolics studied so far (Beecher et al., 1998). The structural characteristic of ferulic acid and its reduced form, ferulaldehyde mainly resembles, the difference is one functional group (Figure 6). Due to this structural similarity and the presence of the reactive aldehyde group (which can be easily oxidized to carboxylic group), ferulaldehyde is thought to have very similar or maybe better biological activity as ferulic acid (Radnai et al, 2009; Tucsek et al., 2011). 


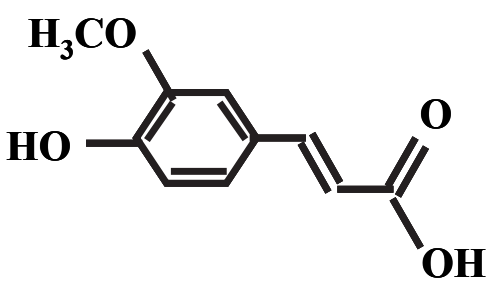

Ferulic acid

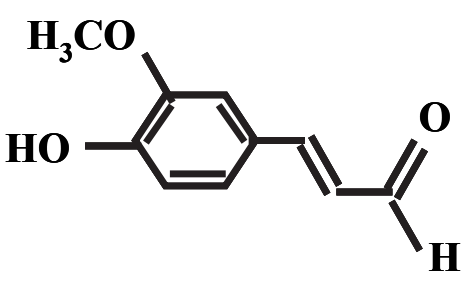

Ferulaldehyde

Fig. 6. Structure of ferulic acid and ferulaldehyde

\section{Pathomechanism of sepsis}

\subsection{Reactive oxygen and nitrogen species}

Oxidative stress is involved in the pathomechanism of sepsis and reactive oxygen and nitrogen species are important mediators of cellular injury during endotoxemia (Cadenas \& Cadenas, 2002). Oxidative damage caused by ROS and RNS will lead, among others, to DNA lesions, function loss of enzymes, increased cell permeability, disturbed signalling over the cell and eventually even cell death via necrosis or apoptosis. Consequently, ROS play a key role in enhancing the inflammation through sustained production of various cytokines, activation and phosphorylation of MAP kinases and redox-sensitive transcription factors, such as NF-kB and AP-1 in various inflammatory diseases. ROS also alters nuclear histone acetylation and deacetylation (chromatin remodelling) leading to increased gene expression of proinflammatory mediators (Rahman et al., 2004). ROS are generated during normal cellular metabolism. The respiratory chain in mitochondria is the major source of oxygen radicals. In inflammatory processes, beside the mitochondrial ROS production there are other possible sources of ROS such as metabolic cascade of arachidonic acid (via COX-2), protease-mediated enzyme xanthine-oxidase and membrane-bound enzyme complex NADPH oxidase (Victor et al., 2005). ROS and RNS cause peroxidation of membrane phospholipids, oxidation of proteins and DNA damage (Pattanaik \& Prasad 1996). iNOS is expressed and continuously active during inflammation, where it is involved in host- 
defence against pathogens. iNOS generates NO which can be converted to its stable products, nitrite and nitrate (Gomez-Jimenez et al., 1995).

Many studies reconfirmed the fact that resveratrol is a potent free radical scavenger and also a potent antioxidant (Soleas et al., 1997). Peripheral blood mononuclear cells play a critical role as the first defence line during endotoxemia. Activation of these cells by different physiological and non physiological agents causes a massive respiratory burst followed by an increase in oxygen consumption accompanied by the generation of ROS including superoxide, hydrogen peroxide, and hydroxy radicals. The release of ROS is of major importance for host defence but can also induce tissue damage. Resveratrol has been reported to have a strong inhibitory effect on multiple reactive oxygen species produced by polymorphonuclear leukocytes stimulated with formyl methionyl leucyl phenylalanine a chemotactic peptide (Rotondo et al., 1998). Zymosan is a carbohydrate-rich cell wall preparation derived from the yeast Saccharomyces cerevisiae could activate leukocytes to release ROS and resveratrol was shown as a potent inhibitor of ROS production in both unopsonized zymosan-stimulated RAW 264.7 cells and human monocytes and neutrophils (Jang et al., 1999). It was reported that resveratrol exerted a strong inhibitory effect on superoxide radical and hydrogen peroxide produced by macrophages stimulated by lipopolysaccharides (LPS) or phorbol esters (Martinez \& Moreno, 2000).

Quercetin has been shown to be an excellent in vitro antioxidant. Within the flavonoid family, quercetin is the most potent scavenger of ROS, including superoxide (Hanasaki et al., 1994; Cushnie \& Lamb, 2005), and RNS like NO (van Acker et al., 1995) and peroxynitrite (Haenen et al., 1997; Heijnen et al., 2001) and it also contributes to the total plasma antioxidant capacity (Arts et al., 2004). On the other hand, it is known that during its antioxidative activities, quercetin becomes oxidized into various oxidation products and these products like semiquinone radicals and quinones display various toxic effects, such as increased membrane permeability, due to their ability of arylating protein thiols (Kalyanaraman et al., 1987; Monks \& Lau, 1992; Metodiewa et al., 1999). However, quercetin quinone-induced toxicity has been shown in various in vitro studies and has recently been defined as the quercetin paradox (Boots et al., 2007), its in vivo formation and possible toxicity has not been demonstrated yet.

Free radicals such as superoxide anion, hydrogen peroxide, and nitric oxide have been reported to be scavenged by curcumin (in the micro to millimolar range) both in vitro and in vivo (Aggarwal et al., 2003). The antioxidant properties of curcumin are evident from its ability to lower lipid peroxidation and maintain the activity status of various antioxidant enzymes. Findings of Biswas et al. indicate that curcumin could scavenge ROS, as determined by electron paramagnetic resonance spectroscopy and it was found to be much faster in terms of quenching ROS when compared to resveratrol and quercetin. Curcumin has also been demonstrated to induce antioxidant defences through increases in glutathione production via Nrf2 activation and induction of glutamate cysteine ligase transcription and interacting directly with superoxide anion and hydroxyl radical (Biswas et al., 2005). In addition, curcumin had an effective scavenging activity in various in vitro antioxidant assays, including DPPH radical, ABTS radical, DMPD radical, superoxide anion radical and hydrogen peroxide; ferric ions $\left(\mathrm{Fe}^{3+}\right)$ reducing power and ferrous ions $\left(\mathrm{Fe}^{2+}\right)$ chelating activities (Ak \& Gülçin, 2008). This suggests that curcumin has multiple anti-inflammatory properties: as an oxygen radical scavenger and as an antioxidant through modulation of glutathione levels. 
Tea polyphenols have been reported to be potent scavengers (more efficient than vitamin $\mathrm{E}$ and C) (Nanjo et al., 1996; Pannala et al., 1997) of free radicals such as singlet oxygen, superoxide anions, hydroxyl radicals, and peroxy radicals in a number of in vitro systems (Salah et al., 1995; Morel et al., 1999) and EGCG was found to be the strongest antioxidant among tea catechins (Khokhar \& Magnusdottir, 2002). EGCG attenuated 3hydroxykynurenine, a potential neurotoxin in several neurodegenerative disorders, induced cell viability reduction and the increase in the concentration of ROS and caspase- 3 activity in neuronal culture were also attenuated, presumably via its antioxidant activity (Jeong et al., 2004). In rat brain tissue, green tea and black tea extracts were shown to inhibit lipid peroxidation promoted by iron ascorbate in homogenates of brain mitochondrial membranes (Levites et al., 2002). A similar effect was also reported using brain synaptosomes, in which the four major polyphenol catechins of green tea were shown to inhibit iron-induced lipid peroxidation (Guo et al., 1996). The ability of green tea polyphenols and catechins, in particular, to chelate metal ions such as iron and copper may contribute to their antioxidant activity by inhibiting transition metal-catalyzed free radical formation. Furthermore, EGCG treatment inhibited the enzyme iNOS (Lin \& Lin, 1997; Lin et al., 1999) in activated macrophages. On the other hand, EGCG was found to elevate the activity of two major antioxidant enzymes, superoxide dismutase (SOD) and catalase in mice striatum (Levites et al., 2001). Taken together, the inhibition of enzymes, whose activity may promote oxidative stress and an increase in antioxidant enzyme activities by tea polyphenols might have a beneficial significance to anti-inflammatory processes.

Phenolic acids and aldehydes have been reported to exert antioxidant and antiinflammatory effects. Phenolic compounds can trap the free radicals directly or scavenge them through a series of coupled reactions with antioxidant enzymes. Caffeic acid has been shown to protect tissues from ROS-mediated oxidative stress and inhibit lipoxygenase activity resulting in suppressed lipid peroxidation (Yilmaz et al., 2004). It was demonstrated that administration of caffeic acid reduced oxidative stress by increasing antioxidant activities and decreasing oxidant status and lipid peroxidation in the intestine of rats in an experimental model of necrotizing enterocolitis (Tayman et al., 2011). Administration of caffeic acid has been also shown to completely block both the production of ROS from activated neutrophils and the XO system (Ma et al., 2006; Yildiz et al., 2009) and to protect intestinal tissues from ROS-mediated oxidative stress and reduce lipid peroxidation (Ek et al., 2008; Koltuksuz et al., 1999). Treatment of rats orally with caffeic acid resulted in a significant decrease in iron nitrilotriacetate-induced xanthine oxidase, lipid peroxidation, cglutamyl transpeptidase, and $\mathrm{H}_{2} \mathrm{O}_{2}$ and there was a dose dependent and significant recovery of renal glutathione content and antioxidant enzymes (Rehman \& Sultana, 2011). Caffeic acid has also been shown to be an inhibitor of the lipoxygenase enzyme in several experimental systems (Okutan et al., 2005). In addition, caffeic acid is an effective ABTS radical scavenging, DPPH radical scavenging, superoxide anion radical scavenging and it has total reducing power and metal chelating on ferrous ions activities (Gulcin, 2006).

In wheat grain ferulic acid is the most abundant phenolic compounds and a correlation between changes in the plasma ferulic acid concentration and changes in the plasma antioxidant capacity was reported in a human ex vivo study (Mateo Anson et al., 2011). The antioxidant potential of ferulic acid can usually be attributed to its structural characteristic. Three distinctive motifs (3-methoxy and 4-hydroxy groups on the benzene ring, and the carboxylic acid group) of ferulic acid are responsible for its free radical scavenging capability. It has been also reported that ferulic acid or related ester derivatives inhibited the 
release of ROS and RNS via suppression of iNOS (Jiang et al., 2009) and COX-2 (Hirata et al., 2005, Ronchetti et al., 2009) in LPS-stimulated macrophages. Its reduced form, ferulaldehyde possesses the same structural characteristic and main molecular motifs as ferulic acid up to the aldehyde group. Ferulaldehyde was reported to inhibit LPS-induced iNOS expression and NO synthesis in murine macrophage-like RAW 264.7 cells (Kim et al., 1999) and to have a good antioxidant activity in about the same degree as ferulic acid (Nenadis et al., 2003). Furthermore, ferulaldehyde decreased free radical and nitrite production in a concentrationdependent manner in LPS plus interferon-gamma-treated primary mouse hepatocytes and in LPS-induced RAW 264.7 macrophage cells (Radnai et al., 2009; Tucsek et al., 2011).

Taken together these studies have shown that polyphenols are more effective in inhibiting the oxidative damage than the conventional antioxidants and has also been shown to scavenge free radicals such as nitric oxide, lipid hydroperoxyl, hydroxyl, and superoxide anion radicals. Since reactive oxygen and nitrogen species have been implicated in the pathogenesis of various chronic and inflammatory conditions, polyphenols therefore have the potential to control these diseases through their potent antioxidant activity.

\subsection{Inflammatory cytokines}

The immune system produces cytokines and other humoral factors to protect the host when threatened by inflammatory agents, microbial invasion, or injury. The pathogenesis of sepsis is characterized by an overwhelming production of proinflammatory cytokines, such as tumor necrosis factor (TNF)- $\alpha$, interleukin (IL)-1 $\beta$, IL-6, IL-8 and high mobility group box (HMGB)-1. In some cases these cytokines trigger a beneficial inflammatory response that restores normal homeostasis promoting local coagulation to control tissue damage. However, the overproduction of immunoregulatory mediators can be even more dangerous than the original stimulus, overcoming the normal regulation of the immune response and producing pathological inflammatory disorders (Dinarello, 1994; Hotchkiss \& Karl, 2003; Tracey \& Cerami, 1993; Tracey \& Cerami, 1994; Van der Poll \& Lowry, 1995). In severe sepsis the excessive production of proinflammatory cytokines causes capillary leakage, tissue injury, multiple organ failure, coma and death. TNF- $\alpha$, a polypeptide cytokine produced during infection, injury, or invasion, has proved pivotal in triggering the lethal effects of septic shock syndrome and other systemic manifestations of disease. If the infection spreads, however, excessive TNF- $\alpha$ production and release into the circulation may be catastrophic and trigger a state of lethal shock via cardiovascular collapse. These toxic effects occur by direct action of TNF-a on host cells and by the interaction with a cascade of other endogenous mediators including IL-1, IL-6 and interferon-gamma (Tracey \& Cerami, 1993; Tracey \& Cerami, 1994). Similar to TNF-a and HMGB1, several proinflammatory cytokines and factors, such as IL-1 (Dinarello, 1994), IL-6, IL-8 (Calandra et al., 1990; Hotchkiss et al., 2000) macrophage migration inhibitory factor (Parrish et al., 2008) and lysophosphatidylcholine (Kabarowski et al., 2001), contribute to the pathogenesis and progression of sepsis. Sepsis is characterized by a surge of the pro-inflammatory cytokines TNF- $\alpha$ and IL-1 at the early stage. However, as the disease progresses, this early stage coverts to the anti-inflammatory state, marked by decreased levels of TNF-a and increased levels of IL-10 (Scumpia \& Moldawer, 2005). The increased production of IL-10 in the late phase of sepsis is believed to contribute to 'immunosuppression'. In contrast with early cytokines, such as TNF- $\alpha$ and IL-1, which are produced within minutes after infection, HMGB-1 is a late mediator of sepsis that might be a potential therapeutic target to treat 'established' sepsis. The effects on the balance between pro- and anti-inflammatory cytokine 
expressions have been shown to be specific for specific cytokines and influenced by the structures of polyphenols indicating the complex action exerted by these compounds. Since cytokine-based strategies against septic shock and severe sepsis have produced modest effects in clinical trials (Abraham et al., 2001; Fisher et al., 1994) novel therapeutic approaches are needed and polyphenols are perfect candidates for this role.

The release of various cytokines after various stimuli from macrophages and lymphocytes, such as IL-6 (Feng et al., 2002; Zhong et al., 1999), IFNY, IL-2, TNF-a, and IL-12 (Gao et al., 2001), has been shown to be inhibited by resveratrol. Resveratrol was also reported to suppress the activity of T- and B-cells, and macrophages the major cell types responsible for producing cytokines by decreasing the production of proinflammatory proteins, (Sharma et al., 2007) and it was able to reduce TNF-a, IL-1 $\beta$, IL-6, and COX-2 gene expression and to reduce the secretion of IL-6 and PGE2 in TNF-a-stimulated adipocytes (Gonzales \& Orlando, 2008). In an age-related diseases study, mice treated with resveratrol had decreased expression of the inflammatory markers TNF- $\alpha$, IL-1 $\beta$, IL-6, intercellular adhesion molecule (ICAM)-1 and iNOS (Pearson et al., 2008). In a mouse model of chronic colitis, resveratrol treatment resulted in significant decreases in the inflammatory cytokines TNF- $\alpha$ and IL-1 $\beta$, as well as COX-2 and iNOS activity and an increase in the anti-inflammatory, immune-regulatory cytokine, IL-10 (Sánchez-Fidalgo et al., 2010). Resveratrol administration following trauma-hemorrhage decreased IL-6 cytokine production and protected against lung injury and inflammation in rats (Wu et al., 2008). In a rodent model of LPS-induced airway inflammation resveratrol caused a dose-related inhibition of TNF- $\alpha$, IL-1 $\beta$, MPO, and CINC-1 levels in the lung tissue (Birrell et al., 2005) and in a human study resveratrol inhibited the release of inflammatory cytokines IL-8 and granulocyte-macrophage colonystimulating factor from alveolar macrophages in chronic obstructive pulmonary disease (Culpitt et al., 2003). However, it is interesting to mention that many of the proinflammatory genes inhibited by resveratrol in several different vitro studies, are not impacted on in vivo models indicating the host and tissue specificity of this polyphenol (Birrell et al., 2005).

Several in vitro studies using different cell lines have shown that quercetin is also capable of inhibiting LPS-induced cytokine production. For instance, quercetin inhibits LPSinduced TNF-a production in macrophages (Manjeet \& Ghosh, 1999) and LPS-induced IL8 production in lung cells (Geraets et al., 2007). Moreover, in glial cells it was shown that quercetin can inhibit LPS-induced mRNA levels of two cytokines, i.e. TNF-a and IL-1a (Bureau et al., 2008). It has already been shown that quercetin can inhibit the production as well as the gene expression of TNF- $\alpha$ via modulation of NF- $\mathrm{KB}$ in human peripheral blood mononuclear cells (Nair et al., 2006). Results indicate that TNF-a and IL-6 accumulations were significantly reduced by quercetin treatment, in murine RAW 264.7 macrophages treated with LPS (Jung \& Sung, 2004). Cho and colleagues reported that in the same cell line pretreatment of quercetin inhibited iNOS mRNA, iNOS protein, NO production, TNF-a, IL-1 $\beta$ and IL-6 (Cho et al., 2003). Quercetin has also been reported to inhibit IgE-mediated release of histamine, tryptase and production and gene expression of inflammatory cytokines, such as TNF- $\alpha$, IL-1 $\beta$, IL-6 and IL-8 in phorbol 12-myristate 13acetate and calcium ionophore-stimulated cultured human mast cells (Kempuraj et al., 2005; Min et al., 2007). These results are consistent with studies reporting that quercetin inhibits NO and TNF-a release from LPS-stimulated rat Kupffer cells (Kawada et al., 1998) and inhibits iNOS mRNA and NO production in LPS/IFN- $\gamma$-activated macrophage cells (Kobuchi et al., 1997). 
In 1995 it was demonstrated by Chan that curcumin inhibits LPS-induced production of TNF- $\alpha$ and interleukin IL-1 $\beta$ in human monocytic macrophage cell line, Mono Mac 6 and it reduced the biological activity of TNF in L929 fibroblast lytic assay (Chan, 1995). Since this original work, several line of evidence appeared about curcumin's inhibitory effect on inflammatory cytokines. In LPS-stimulated BV2 microglia cells curcumin significantly inhibited the release of pro-inflammatory cytokines in a dose-dependent manner (Jin et al., 2007). Moreover, decreased expression of inflammatory cytokines such as IL-1 $\beta$, IL-6, and TNF- $\alpha$ was reported in different cancer cell lines (Cho et al., 2007). In other studies, curcumin inhibited the production of IL-8, MIP-1 $\alpha$, MCP-1, IL-1 $\beta$ and TNF- $\alpha$ by PMA- or LPS-stimulated human monocytes and alveolar macrophages in a concentration- and a timedependent manner (Abe et al., 1999; Chan, 1995). The in vivo effects of curcumin on cytokine production are also demonstrated in different model systems. In two rat models of experimentally-induced pancreatitis, curcumin decreased inflammation by markedly inhibiting mRNA induction of IL-6, TNF- $\alpha$ and iNOS in the pancreas (Gukovsky et al., 2003). Curcumin decreased the levels of TNF- $\alpha$ and interleukin-6 in mouse plasma after endotoxin-induced hepatic dysfunction and oxidative stress (Kaur et al., 2006) and also inhibited the increase of both IL-1 $\beta$ and TNF- $\alpha$ in a chronic model of inflammation in rats (Banerjee et al., 2003). Systemic pretreatment with curcumin abrogates the rise in circulating proinflammatory cytokines and body temperature (Lee et al., 2003) and prevents the onset of disseminated intravascular coagulation (Chen et al., 2007).

The effects of EGCG on the inflammatory cytokine production are thought to be cell typedependent. EGCG was reported to inhibit TNF-a and MIP-2 production from the RAW 264.7 cells treated with LPS (Yang et al., 1998). Okabe et al reported, that EGCG effectively prevented TNF-a release in BALB/3T3 cells stimulated with okadaic acid (Okabe et al., 2001). EGCG, recapitulated HMGB1-inhibiting activities of green tea, and dose-dependently inhibited LPS-induced HMGB1 release in macrophage/monocytes cultures, partially attenuated LPS-induced TNF secretion. EGCG prevents HMGB1-mediated cytokine production-potentially by interfering with HMGB1-induced ligand/receptor clustering (Li et al., 2007). Experimental data suggest that EGCG selectively inhibits LPS-induced release of HMGB1, TNF, IL-6, IL-12, and chemokines, including MIP-1a, MIP-1c, MIP-2, RANTES, KC, MCP1 and CXCL16. EGCG did not affect circulating levels of TNF at late stage of sepsis, but specifically attenuated systemic accumulation of HMGB1, as well as IL-6 and KC-two most reliable surrogate markers of lethal sepsis (Osuchowski et al., 2006; Heuer et al., 2004). Effects of EGCG on the production of IL-8, human homolog of murine CXC-chemokines, have also been reported in selected cell lines. It was shown that EGCG inhibited IL-8 production in HMC-1 cells (Shin et al., 2007), A549 bronchial epithelial cells (Kim et al., 2006), HT29, T84 (Porath et al., 2005) and gastrointestinal epithelial cell line Caco-2 cells (Netsch et al., 2006). In vivo, EGCG attenuated the production of TNF-a and MIP-2 in the lungs of mice administered with LPS intratracheally (Bae et al., 2010). Li et al provided both evidence of a lifesaving potential and a mechanism of action for an EGCG therapeutic regimen in mice subjected to cecal ligation and puncture (CLP). EGCG reduced the mortality rate and concentrations of IL-6, keratinocyte-derived chemokine (a mouse IL-8 homologue), and HMGB-1, but not those of TNF- $\alpha$, were significantly reduced. Exposure of monocytes and macrophages to EGCG in vitro reduced HMGB-1 release following LPS stimulation and IL-6 production and EGCG inhibited HMGB-1 aggregation on the macrophage cell surface. HMGB-1 antagonism was evident even when EGCG treatment of stimulated cells was delayed by $6 \mathrm{~h}$. Potential therapeutic uses of EGCG is further 
strengthened by the fact that EGCG treatment is operative even when it is initiated after the onset of full-blown sepsis (Li et al., 2007).

Phenolic acids are clinically important inhibitors of inflammatory cytokine production in vitro and in vivo. Caffeic acid phenethyl ester (CAPE) is a potent inhibitor of early and late events in T-cell receptor-mediated T-cell activation. Moreover, it was found that CAPE specifically inhibited both IL-2 gene transcription and IL-2 synthesis in stimulated T-cells (Márquez et al., 2004). In activated human whole blood cultures, caffeic acid decreased the production of IL-1 $\beta$ without affecting IL-6 concentration (Miles et al., 2005) suggesting the specificity of this phenolic compound on interleukin production. In CLP-induced sepsis and lung injury model in rats, similarly to EGCG, CAPE was found to decrease IL-1, IL-6, IL-10, and TNF-a levels of blood samples even when it was administered after the onset of sepsis. (Fidan et al., 2007). In another in vivo study, CAPE rescued C57BL/ 6 mice from lethal LPSinduced septic shock, while decreasing serum levels of TNF-a and IL-1 $\beta$ (Jung et al., 2008). The other large family of phenolic acids: ferulic acid and its derivatives were also attributed as potent inhibitors of inflammatory mediators. Indeed, ferulic acid decreased the levels of inflammatory cytokines, e.g., TNF-a (Han et al., 2007) in LPS-stimulated macrophages and lowered pro-:anti-inflammatory cytokine ratios (IL-6:IL-10 and IL-1 $\beta$ :IL-10) in the ex vivo LPS-stimulated blood (Mateo Anson et al., 2011). Ferulaldehyde decreased the levels of early pro-inflammatory cytokines such as TNF- $\alpha$, IL-1 $\beta$ and increased the anti-inflammatory IL-10 in the sera of the LPS-treated mice (Radnai et al., 2009; Tucsek et al, 2011) supporting further the importance of these compounds as potential anti-inflammatory agents.

\subsection{Signaling pathways}

Polyphenols can work as modifiers of signal transduction pathways to elicit their beneficial effects. The anti-inflammatory effect of these natural compounds based on the modulation of pro-inflammatory gene expression such as cyclooxygenase, lipoxygenase, nitric oxide synthases and several inflammatory cytokines, mainly by acting through NF-kB and MAPK signalling (Yoon \& Baek, 2005). MAPKs and NF-kB have important activities as mediators of cellular responses to extracellular signals. Some of the MAPKs are important to mammalian cells include extracellular signal regulated kinase (ERK), c-jun N-terminal kinase (JNK), and p38 and are thought to play an important role in the regulation of pro-inflammatory molecules on cellular responses (Azzolina et al., 2003; Baldassare et al., 1999). Because of their essential role in intracellular signalling network, MAPK pathways and the connected transcription factors are appropriate targets for pharmacological treatment of inflammatory disorders (Lewis et al., 1998) and polyphenols are extensively investigated as possible regulatory molecules in this process.

Inflammation involves a cross-talk between several transcription factors, kinases and intracellular and intercellular cytokines involving NF-kB, MAPKs, PKC, PI-3-kinases etc. There has been considerable amount of evidence confirming that resveratrol takes active part in the modulation of these cell signalling molecules. Although resveratrol has been shown to target various intracellular signaling molecules in cultured cell lines, the molecular mechanisms underlying anti-inflammatory activity of resveratrol in vivo remain largely unresolved. Since NF-kB activation is critically linked to inflammatory responses and other chronic diseases associated with ROS and RNS production (Karin et al., 2004) the effect of resveratrol on NF-kB has been studied intensively in the last decade (Holmes-McNary \& Baldwin, 2000; Manna et al., 2000) Indeed, resveratrol is a potent inhibitor of wide variety of inflammatory agents-induced activation of NF-KB, and this inhibition is not cell type 
specific. Some molecular targets of resveratrol are identified in toll-like receptor (TLR)mediated signalling pathways. It has been reported that resveratrol acts on NF-kB by the inhibition of ІкB kinase, leading to the inhibition of LPS-induced IкBa degradation, which results in the prevention of translocation of NF-KB into the nucleus (Holmes-McNary \& Baldwin, 2000). It was suggested that IKBa degradation induced by TLR4-TRIF pathway is mediated through the interaction between TRIF and tumor necrosis factor receptorassociated factor 6 (TRAF6) because TRAF6 was shown to associate with the N-terminal part of TRIF (Sato et al., 2003; Jiang et al., 2004). Resveratrol was also shown to inhibit MyD88independent signaling pathways and target expression (Youn et al., 2005). One of the major target molecules subjected to NF-kB-driven transactivation is cyclooxygenase-2, which is the enzyme of the rate-limiting step of the pathway that produces mediators of inflammation. Anti-inflammatory activity of resveratrol and some of its proposed mechanisms of action were attributed mostly in inhibition of COX activity (Das \& Das, 2007; Kundu et al., 2006). Resveratrol also interferes with the pro-inflammatory signalling of thrombin resulting in the inhibition of adenosine nucleotide secretion from activated platelets and decreased neutrophil functions via inhibition of PAP and P2-receptor signalling through MAPK and cJun and JNK (Kaneider et al., 2004). However there is amply evidence about the modulatory effect of resveratrol on MAPK pathways, the data are so cell type and experimental system specific that it is hard to conclude and draw a coherent picture.

It has already been shown that quercetin can inhibit the production as well as the gene expression of TNF-a via modulation of NF-KB in human peripheral blood mononuclear cells (Nair et al., 2006). A possible mechanism behind this modulation was reported to be the inhibition of the degradation of the inhibitory part (IкBa) of this transcription factor (Peet \& $\mathrm{Li}, 1999)$. In addition, quercetin treatment inhibited NF-KB activation through stabilization of the NF- $\mathrm{KB} / \mathrm{I \kappa B}$ complex leading to inhibition of ІкB degradation and proinflammatory cytokines and NO/iNOS expression in RAW 264.7 macrophages (Cho et al., 2003). NF$\mathrm{KB} / \mathrm{DNA}$ binding activity induced by PMA and calcium ionophore was also markedly suppressed by quercetin without altering the binding activity of AP-1 in human mast cells (Min et al., 2007). In the same model quercetin attenuated the PMA and A23187-induced phosphorylation of p38 MAPK but not JNK or ERK. However, in an LPS-induced macrophage model quercetin strongly reduced activation of phosphorylated ERK kinase and p38 MAP kinase but not JNK MAP kinase (Cho et al., 2003). Moreover, TNF-a secretion in LPS-stimulated RAW macrophages was also shown to be inhibited by quercetin through interfering with the phosphorylation and activation of JNK and its downstream substrates cJun and ATF-2, and ERK1/2 and p38 MAPK (Wadsworth et al., 2001). Although NF-KB inhibition by quercetin in general is supported by several line of evidence the signalling events leading to the blockade of this transcription factor differ from cell to cell and model to model.

Curcumin has been shown to suppress the activation of NF-KB induced by various proinflammatory stimuli, presumably through inhibition of IKK kinase activity or DNA binding of p65. It is likely that curcumin also interferes with NF-kB activation at other points along this pathway, such as downstream to the various receptors that signal to this transcription factor. However, inhibition of IKK by curcumin plays a central role in this mechanism since the lack of phosphorylation of NF-kB suppresses binding of NF- $\mathrm{kB}$ to DNA sequences and as a consequence expression of genes described in vitro in inflammatory and vascular cells stimulated with LPS, staphylococcal enterotoxin A, TNF-a, or IL-1 $\beta$, and in vivo in models of inflammatory diseases (Chan, 1995; Hatcher et al., 2008; 
Jobin et al., 1999; Joe et al., 2004; Pan et al., 2000; Singh \& Aggarwal, 1995). Regarding the LPS/NF-kB pathway, curcumin competes in vitro with LPS for binding to the TLR4/myeloid differentiation factor-2 complex (Gradisar et al., 2007) and prevents TLR-4 homodimerization (Youn et al., 2006), events necessary for MyD88-dependent signalling. Further studies indicated that curcumin which contains unsaturated carbonyl group, but not resveratrol (with no unsaturated carbonyl group), inhibits TLR4 activation by interfering with receptor dimerization. This conclusion was further supported by the finding that curcumin inhibits ligand-independent dimerization of constitutively active TLR4. Inhibition of receptor dimerization of TLR4 suggests that curcumin could modify the free sulfhydryl groups of cysteine residues in TLR4, leading to interference of disulfide formation. Curcumin also induces intracellular heat-shock protein 70 (Dunsmore et al., 2001; Shen et al., 2007), a protein chaperone that protects IKK from proteasomal degradation, thus inhibiting NF-KB translocation to the nucleus. Downstream to NF- $\mathrm{kB}$ curcumin was found to significantly down-regulate the TNF-a-induced increase in MMP-13 mRNA and protein expression in primary human chondrocytes and in human bone chondrosarcoma cells by a mechanism involving the inhibition of c-Jun and JNK (Liacini et al., 2003). Interestingly, a study on experimental colitis in which NF-kB-dependent gene expression, inflammation, and tissue injury were significantly attenuated by curcumin an increase in the intestinal level of PPAR- $\gamma$ was observed (Zhang et al., 2006) indicating a strong connection between the two transcription factor. In conclusion, inactivation of the NF-KB pathway by curcumin appears to occur at multiple levels and to ameliorate the various stages of sepsis-associated inflammation.

EGCG is known to inhibit NF-kB activation induced by many pro-inflammatory stimuli such as UV, LPS, TNF- $\alpha$ and IL-1 $\beta$ (Barthelman et al., 1998; Yang et al., 1998; Yang et al., 2001; Wheeler et al., 2004;) resulting in the decrease in the expression of inflammatory gene products including lipoxygenase (Yang \& Koo, 2000), COX (Soriani et al., 1998), NOS (Chan et al., 1997; Lin \& Lin, 1997), and TNF-a (Yang et al., 1998). It has been shown that the activation of NF-kB was suppressed by EGCG possibly mediated through the suppression of the kinase activity of IKB kinase in macrophages and the intestinal epithelial cell line (IEC6) (Pan et al., 2000; Yang et al., 2001). EGCG was shown to inhibit the activity of IKK $\beta$ which is the key kinase in the canonical pathway for NF-kB activation in MyD88-dependent pathway of TLRs. Moreover, EGCG inhibited the activation of IFN regulatory factor 3 (IRF3) induced by LPS, poly[I:C], or the overexpression of TRIF. The inhibition of IRF3 activation by EGCG was mediated through the suppression of the kinase activity of TANK-binding kinase 1 in TRIF-dependent signalling pathways of TLR3 and TLR4 (Youn et al., 2006). These data indicate that green tea flavonoids, without the structural motif conferring Michael addition, did not inhibit TLR4 dimerization however; they can modulate both MyD88- and TRIF-dependent signalling pathways of TLRs and subsequent inflammatory target gene expression. In addition, Abboud et al demonstrated that EGCG may be beneficial in colitis, which was induced by rectal administration of trinitrobenzene sulfonic acid in C57/BL6 mice, through selective immunomodulatory effects, which may be mediated, at least in part, by inhibition of NF-kB and AP-1 (Abboud et al., 2008). The effects of EGCG on the cellular kinase cascade are rather diversified. In RAW 264.7 cells stimulated with LPS EGCG inhibited the production of TNF-a and MIP-2, and attenuated phosphorylation levels of ERK1/2 and JNK, but not p38. Also, EGCG attenuated the production of TNF- $\alpha$ and MIP-2, and the phosphorylation of ERK1/2 and JNK in the lungs of mice administered with LPS intratracheally (Bae et al., 2010). Recently, Yun, et al. showed 
that EGCG inhibited TNF-a induced phosphorylation of MAPKs family, such as ERK1/2, p38 and JNK in synovial fibroblast (Yun et al., 2008), while others showed that EGCG inhibited LPS-induced activation of p38, but augmented phosphorylation of ERK1/2 in J774.1 macrophage cells (Ichikawa et al., 2004). Inhibition of protein tyrosine kinase activity, reducing c-jun mRNA expression and inhibition of JNK1 activation by EGCG were reported by Yokozawa et al. (Yokozawa \& Dong, 1997). Moreover, green tea polyphenols inhibit p44/42 MAP kinase expression (Lu et al., 1998) and induce the death of smooth muscle cells in a p53- and NF-kB-dependent manner (Ouyang et al., 2004). Taken together, the effects of EGCG on MAPKs phosphorylation are thought to be highly cell type-dependent.

It has been demonstrated that CAPE is a potent and specific inhibitor of NF-KB activation (Natarajan et al., 1996). CAPE inhibits LPS-induced nitric oxide and prostaglandin E2 production in a concentration-dependent manner and inhibits iNOS and COX-2 in RAW 264.7 cells, without significant cytotoxicity. CAPE treatment significantly reduced NF-KB translocation and DNA-binding in LPS-stimulated RAW264.7 cells. This effect was mediated through the inhibition of the degradation of IKB and by inhibition of both p38 mitogenactivated protein kinase and ERK phosphorylation, at least in part by inhibiting the generation of reactive oxygen species (Jung et al., 2008). This biological activity of CAPE could also explain by the finding that this phenolic compound prevented the binding to DNA of the p50/p65 NF-kB in vitro and in vivo (Natarajan et al., 1996). In addition to NF$\mathrm{KB}, \mathrm{CAPE}$ also targets the nuclear factor of activated T-cells (NFAT) signaling pathway that is known to play a critical role in the immune response. CAPE is a potent inhibitor of the NFAT pathway, and the results of Marquez et al. suggest that the calcineurin phosphatase can represent one of the major targets for CAPE, since this compound inhibits NFAT dephosphorylation and nuclear binding to DNA (Márquez et al., 2004). Other phenolic acids (gallic, caffeic, protocatechic, paracoumaric, sinapic, and ferulic acids) were reported to inhibit the activity of AP-1 transcription factor on MCF-7 cells after stimulation by phorbol 12-myristate 13-acetate and NF-kB activity on LPS/IFN-gamma-stimulated RAW 264.7 cells (Chao et al., 2010; Maggi-Capeyron et al., 2001). Similarly to phenolic acids ferulaldehyde also inhibited the activation and nuclear translocation of NF-KB in the liver of LPS-treated mice. In the same model ferulaldehyde significantly prevented the activation of JNK and Akt, but failed to attenuate LPS-induced activation of ERK1/2 (Radnai et al., 2009). Suppressing both LPS-induced JNK and Akt activation, ferulaldehyde inhibited the most important pathways leading to NF-kB activation, namely the LPS/TLR4/JNK and LPS/ PI-3K/Akt pathways. The observation that FA did not show any effect on the LPS-induced activation of ERK1/2 and p38 MAP kinase pathways indicates that FA's inhibitory target(s) is necessarily downstream of the TLR4 receptors. However, unlike the in vivo model, ferulaldehyde attenuated LPS-induced activation of all three MAP kinases suggesting a uniform regulation of MAPK activation in LPS-stimulated macrophages. These results may arise from the differences of the inflammatory models used, and cell- and tissue-specificity of the LPS-induced processes (Veres et al., 2004). MAP kinase phosphatases (MKP), responsible for dephosphorylation and deactivation of MAP kinases, have a central role in the restraint of innate immune response and the prevention of septic shock syndrome during pathogenic microbial infection (Zhao et al., 2006). It is known that MAPK activation is followed by increased MKP-1 expression probably as a compensatory regulatory mechanism. In line with this evidence Tucsek et al found in an in vitro experimental model that ferulaldehyde shifted increased expression of MKP-1 forward in time which in turn attenuated activation of MAP kinases (Tucsek et al., 2011). 


\section{Conclusion}

A number of different approaches have been investigated to try to treat and/or prevent septic shock and sepsis. Despite advances in elucidating its pathophysiology, severe sepsis remains a leading cause of death in the critically ill. It has been widely shown that many plant-derived compounds present anti-inflammatory effects. Polyphenols and their degradation products can exert their anti-inflammatory properties at multiple levels, through the modulation of MAPK, Akt and NF-KB signalling pathways, inhibition the production of inflammatory cytokines and chemokines, suppressing the activity of COX and iNOS and decreasing the production of ROS/RNS. Importantly, efficacy is maintained in some cases even when treatment is initiated hours after the onset of sepsis. These agents would be useful not only for the treatment of inflammatory disorders, but also for the control of some other diseases which present an inflammatory origin. However, the majority of the anti-inflammatory studies on plant-derived compounds have been carried out in vitro the polyphenols reviewed in this chapter appear to be safe and to exert anti-inflammatory effects in in vivo studies and even in humans. Thus, polyphenols and their degradation products represent a new, effective family of anti-inflammatory drugs that may help to prevent and treat sepsis.

\section{Acknowledgment}

I would like to thank Dr. Peter Jakus for his excellent editorial assistance. The author is grateful for the thoughtful suggestions and discussions from the members of the "Septic Shock Team" (Balazs Radnai and Zsuzsanna Tucsek). I sincerely apologize to those authors whose work could not be cited.

\section{References}

Abboud, P. A., Hake, P. W., Burroughs, T. J., Odoms, K., O'Connor, M., Mangeshkar, P., Wong, H. R. \& Zingarelli, B. (2008). Therapeutic effect of epigallocatechin-3-gallate in a mouse model of colitis. Eur J Pharmacol, Vol. 579, No. 1-3, (Jan 28), pp. (411417), 0014-2999 (Print)

Abe, Y., Hashimoto, S. \& Horie, T. (1999). Curcumin inhibition of inflammatory cytokine production by human peripheral blood monocytes and alveolar macrophages. Pharmacol Res, Vol. 39, No. 1, (Jan), pp. (41-47), 1043-6618 (Print)

Abraham, E., Laterre, P. F., Garbino, J., Pingleton, S., Butler, T., Dugernier, T., Margolis, B., Kudsk, K., Zimmerli, W., Anderson, P., Reynaert, M., Lew, D., Lesslauer, W., Passe, S., Cooper, P., Burdeska, A., Modi, M., Leighton, A., Salgo, M. \& Van der Auwera, P. (2001). Lenercept (p55 tumor necrosis factor receptor fusion protein) in severe sepsis and early septic shock: a randomized, double-blind, placebo-controlled, multicenter phase III trial with 1,342 patients. Crit Care Med, Vol. 29, No. 3, (Mar), pp. (503-510), 0090-3493 (Print)

Aggarwal, B. B., Kumar, A. \& Bharti, A. C. (2003). Anticancer potential of curcumin: preclinical and clinical studies. Anticancer Res, Vol. 23, No. 1A, (Jan-Feb), pp. (363398), 0250-7005 (Print)

Aggarwal, B. B. \& Shishodia, S. (2006). Molecular targets of dietary agents for prevention and therapy of cancer. Biochem Pharmacol, Vol. 71, No. 10, (May 14), pp. (1397-1421), 0006-2952 (Print) 
Ak, T. \& Gulcin, I. (2008). Antioxidant and radical scavenging properties of curcumin. Chem Biol Interact, Vol. 174, No. 1, (Jul 10), pp. (27-37), 0009-2797 (Print)

Arts, I. C., Sesink, A. L., Faassen-Peters, M. \& Hollman, P. C. (2004). The type of sugar moiety is a major determinant of the small intestinal uptake and subsequent biliary excretion of dietary quercetin glycosides. Br J Nutr, Vol. 91, No. 6, (Jun), pp. (841847), 0007-1145 (Print)

Azzolina, A., Bongiovanni, A. \& Lampiasi, N. (2003). Substance P induces TNF-alpha and IL-6 production through NF kappa B in peritoneal mast cells. Biochim Biophys Acta, Vol. 1643, No. 1-3, (Dec 7), pp. (75-83), 0006-3002 (Print)

Babu, P. V. \& Liu, D. (2008). Green tea catechins and cardiovascular health: an update. Curr Med Chem, Vol. 15, No. 18, pp. (1840-1850), 0929-8673 (Print)

Bae, H. B., Li, M., Kim, J. P., Kim, S. J., Jeong, C. W., Lee, H. G., Kim, W. M., Kim, H. S. \& Kwak, S. H. (2010). The effect of epigallocatechin gallate on lipopolysaccharideinduced acute lung injury in a murine model. Inflammation, Vol. 33, No. 2, (Apr), pp. (82-91), 1573-2576 (Electronic)

Baldassare, J. J., Bi, Y. \& Bellone, C. J. (1999). The role of p38 mitogen-activated protein kinase in IL-1 beta transcription. J Immunol, Vol. 162, No. 9, (May 1), pp. (53675373), 0022-1767 (Print)

Banerjee, M., Tripathi, L. M., Srivastava, V. M., Puri, A. \& Shukla, R. (2003). Modulation of inflammatory mediators by ibuprofen and curcumin treatment during chronic inflammation in rat. Immunopharmacol Immunotoxicol, Vol. 25, No. 2, (May), pp. (213-224), 0892-3973 (Print)

Barthelman, M., Bair, W. B., 3rd, Stickland, K. K., Chen, W., Timmermann, B. N., Valcic, S., Dong, Z. \& Bowden, G. T. (1998). (-)-Epigallocatechin-3-gallate inhibition of ultraviolet B-induced AP-1 activity. Carcinogenesis, Vol. 19, No. 12, (Dec), pp. (22012204), 0143-3334 (Print)

Beecher, G. R. (1998). Nutrient content of tomatoes and tomato products. Proc Soc Exp Biol Med, Vol. 218, No. 2, (Jun), pp. (98-100), 0037-9727 (Print)

Birrell, M. A., McCluskie, K., Wong, S., Donnelly, L. E., Barnes, P. J. \& Belvisi, M. G. (2005). Resveratrol, an extract of red wine, inhibits lipopolysaccharide induced airway neutrophilia and inflammatory mediators through an NF-kappaB-independent mechanism. FASEB J, Vol. 19, No. 7, (May), pp. (840-841), 1530-6860 (Electronic)

Bischoff, S. C. (2008). Quercetin: potentials in the prevention and therapy of disease. Curr Opin Clin Nutr Metab Care, Vol. 11, No. 6, (Nov), pp. (733-740), 1363-1950 (Print)

Biswas, S. K., McClure, D., Jimenez, L. A., Megson, I. L. \& Rahman, I. (2005). Curcumin induces glutathione biosynthesis and inhibits NF-kappaB activation and interleukin-8 release in alveolar epithelial cells: mechanism of free radical scavenging activity. Antioxid Redox Signal, Vol. 7, No. 1-2, (Jan-Feb), pp. (32-41), 1523-0864 (Print)

Boocock, D. J., Faust, G. E., Patel, K. R., Schinas, A. M., Brown, V. A., Ducharme, M. P., Booth, T. D., Crowell, J. A., Perloff, M., Gescher, A. J., Steward, W. P. \& Brenner, D. E. (2007). Phase I dose escalation pharmacokinetic study in healthy volunteers of resveratrol, a potential cancer chemopreventive agent. Cancer Epidemiol Biomarkers Prev, Vol. 16, No. 6, (Jun), pp. (1246-1252), 1055-9965 (Print)

Boots, A. W., Haenen, G. R. \& Bast, A. (2008). Health effects of quercetin: from antioxidant to nutraceutical. Eur J Pharmacol, Vol. 585, No. 2-3, (May 13), pp. (325-337), 0014-2999 (Print) 
Boots, A. W., Li, H., Schins, R. P., Duffin, R., Heemskerk, J. W., Bast, A. \& Haenen, G. R. (2007). The quercetin paradox. Toxicol Appl Pharmacol, Vol. 222, No. 1, (Jul 1), pp. (89-96), 0041-008X (Print)

Bravo, L. (1998). Polyphenols: chemistry, dietary sources, metabolism, and nutritional significance. Nutr Rev, Vol. 56, No. 11, (Nov), pp. (317-333), 0029-6643 (Print)

Bureau, G., Longpre, F. \& Martinoli, M. G. (2008). Resveratrol and quercetin, two natural polyphenols, reduce apoptotic neuronal cell death induced by neuroinflammation. J Neurosci Res, Vol. 86, No. 2, (Feb 1), pp. (403-410), 1097-4547 (Electronic)

Cadenas, S. \& Cadenas, A. M. (2002). Fighting the stranger-antioxidant protection against endotoxin toxicity. Toxicology, Vol. 180, No. 1, (Oct 30), pp. (45-63), 0300-483X (Print)

Calandra, T., Baumgartner, J. D., Grau, G. E., Wu, M. M., Lambert, P. H., Schellekens, J., Verhoef, J. \& Glauser, M. P. (1990). Prognostic values of tumor necrosis factor/cachectin, interleukin-1, interferon-alpha, and interferon-gamma in the serum of patients with septic shock. Swiss-Dutch J5 Immunoglobulin Study Group. J Infect Dis, Vol. 161, No. 5, (May), pp. (982-987), 0022-1899 (Print)

Chan, J. H. \& Chan, D. S. (1997). Computer program for tracking incidence of intravasculardevice-related infections in patients receiving parenteral nutrition. Am J Health Syst Pharm, Vol. 54, No. 16, (Aug 15), pp. (1897-1898), 1079-2082 (Print)

Chan, M. M. (1995). Inhibition of tumor necrosis factor by curcumin, a phytochemical. Biochem Pharmacol, Vol. 49, No. 11, (May 26), pp. (1551-1556), 0006-2952 (Print)

Chang, F., Lee, J. T., Navolanic, P. M., Steelman, L. S., Shelton, J. G., Blalock, W. L., Franklin, R. A. \& McCubrey, J. A. (2003). Involvement of PI3K/Akt pathway in cell cycle progression, apoptosis, and neoplastic transformation: a target for cancer chemotherapy. Leukemia, Vol. 17, No. 3, (Mar), pp. (590-603), 0887-6924 (Print)

Chao, C. Y., Mong, M. C., Chan, K. C. \& Yin, M. C. (2010). Anti-glycative and antiinflammatory effects of caffeic acid and ellagic acid in kidney of diabetic mice. Mol Nutr Food Res, Vol. 54, No. 3, (Mar), pp. (388-395), 1613-4133 (Electronic)

Chen, H. W., Kuo, H. T., Chai, C. Y., Ou, J. L. \& Yang, R. C. (2007). Pretreatment of curcumin attenuates coagulopathy and renal injury in LPS-induced endotoxemia. J Endotoxin Res, Vol. 13, No. 1, pp. (15-23), 0968-0519 (Print)

Cheng, A. L., Hsu, C. H., Lin, J. K., Hsu, M. M., Ho, Y. F., Shen, T. S., Ko, J. Y., Lin, J. T., Lin, B. R., Ming-Shiang, W., Yu, H. S., Jee, S. H., Chen, G. S., Chen, T. M., Chen, C. A., Lai, M. K., Pu, Y. S., Pan, M. H., Wang, Y. J., Tsai, C. C. \& Hsieh, C. Y. (2001). Phase I clinical trial of curcumin, a chemopreventive agent, in patients with high-risk or pre-malignant lesions. Anticancer Res, Vol. 21, No. 4B, (Jul-Aug), pp. (2895-2900), 0250-7005 (Print)

Cho, J. W., Lee, K. S. \& Kim, C. W. (2007). Curcumin attenuates the expression of IL-1beta, IL-6, and TNF-alpha as well as cyclin E in TNF-alpha-treated HaCaT cells; NFkappaB and MAPKs as potential upstream targets. Int J Mol Med, Vol. 19, No. 3, (Mar), pp. (469-474), 1107-3756 (Print)

Cho, S. Y., Park, S. J., Kwon, M. J., Jeong, T. S., Bok, S. H., Choi, W. Y., Jeong, W. I., Ryu, S. Y., Do, S. H., Lee, C. S., Song, J. C. \& Jeong, K. S. (2003). Quercetin suppresses proinflammatory cytokines production through MAP kinases andNF-kappaB pathway in lipopolysaccharide-stimulated macrophage. Mol Cell Biochem, Vol. 243, No. 1-2, (Jan), pp. (153-160), 0300-8177 (Print) 
Culpitt, S. V., Rogers, D. F., Fenwick, P. S., Shah, P., De Matos, C., Russell, R. E., Barnes, P. J. \& Donnelly, L. E. (2003). Inhibition by red wine extract, resveratrol, of cytokine release by alveolar macrophages in COPD. Thorax, Vol. 58, No. 11, (Nov), pp. (942946), 0040-6376 (Print)

Cushnie, T. P. \& Lamb, A. J. (2005). Antimicrobial activity of flavonoids. Int J Antimicrob Agents, Vol. 26, No. 5, (Nov), pp. (343-356), 0924-8579 (Print)

D'Archivio, M., Filesi, C., Di Benedetto, R., Gargiulo, R., Giovannini, C. \& Masella, R. (2007). Polyphenols, dietary sources and bioavailability. Ann Ist Super Sanita, Vol. 43, No. 4, pp. (348-361), 0021-2571 (Print)

Das, S. \& Das, D. K. (2007). Anti-inflammatory responses of resveratrol. Inflamm Allergy Drug Targets, Vol. 6, No. 3, (Sep), pp. (168-173), 1871-5281 (Print)

de Boer, V. C., Dihal, A. A., van der Woude, H., Arts, I. C., Wolffram, S., Alink, G. M., Rietjens, I. M., Keijer, J. \& Hollman, P. C. (2005). Tissue distribution of quercetin in rats and pigs. J Nutr, Vol. 135, No. 7, (Jul), pp. (1718-1725), 0022-3166 (Print)

de Lange, D. W. (2007). From red wine to polyphenols and back: a journey through the history of the French Paradox. Thromb Res, Vol. 119, No. 4, pp. (403-406), 0049-3848 (Print)

de Lorgeril, M., Salen, P., Martin, J. L., Monjaud, I., Delaye, J. \& Mamelle, N. (1999). Mediterranean diet, traditional risk factors, and the rate of cardiovascular complications after myocardial infarction: final report of the Lyon Diet Heart Study. Circulation, Vol. 99, No. 6, (Feb 16), pp. (779-785), 0009-7322 (Print)

Dinarello, C. A. (1994). The interleukin-1 family: 10 years of discovery. FASEB J, Vol. 8, No. 15, (Dec), pp. (1314-1325), 0892-6638 (Print)

Donnelly, L. E., Newton, R., Kennedy, G. E., Fenwick, P. S., Leung, R. H., Ito, K., Russell, R. E. \& Barnes, P. J. (2004). Anti-inflammatory effects of resveratrol in lung epithelial cells: molecular mechanisms. Am J Physiol Lung Cell Mol Physiol, Vol. 287, No. 4, (Oct), pp. (L774-783), 1040-0605 (Print)

Dunsmore, K. E., Chen, P. G. \& Wong, H. R. (2001). Curcumin, a medicinal herbal compound capable of inducing the heat shock response. Crit Care Med, Vol. 29, No. 11, (Nov), pp. (2199-2204), 0090-3493 (Print)

Egan, M. E., Pearson, M., Weiner, S. A., Rajendran, V., Rubin, D., Glockner-Pagel, J., Canny, S., Du, K., Lukacs, G. L. \& Caplan, M. J. (2004). Curcumin, a major constituent of turmeric, corrects cystic fibrosis defects. Science, Vol. 304, No. 5670, (Apr 23), pp. (600-602), 1095-9203 (Electronic)

Ek, R. O., Serter, M., Ergin, K., Yildiz, Y., Cecen, S., Kavak, T. \& Yenisey, C. (2008). The effects of caffeic acid phenethyl ester (CAPE) on TNBS-induced colitis in ovariectomized rats. Dig Dis Sci, Vol. 53, No. 6, (Jun), pp. (1609-1617), 0163-2116 (Print)

Feng, Y. H., Zou, J. P. \& Li, X. Y. (2002). Effects of resveratrol and ethanol on production of pro-inflammatory factors from endotoxin activated murine macrophages. Acta Pharmacol Sin, Vol. 23, No. 11, (Nov), pp. (1002-1006), 1671-4083 (Print)

Fidan, H., Sahin, O., Yavuz, Y., Kilbas, A., Cetinkaya, Z., Ela, Y., Ozen, O. A. \& Altuntas, I. (2007). Caffeic acid phenethyl ester reduces mortality and sepsis-induced lung injury in rats. Crit Care Med, Vol. 35, No. 12, (Dec), pp. (2822-2829), 0090-3493 (Print)

Fisher, C. J., Jr., Dhainaut, J. F., Opal, S. M., Pribble, J. P., Balk, R. A., Slotman, G. J., Iberti, T. J., Rackow, E. C., Shapiro, M. J., Greenman, R. L. \& et al. (1994). Recombinant 
human interleukin 1 receptor antagonist in the treatment of patients with sepsis syndrome. Results from a randomized, double-blind, placebo-controlled trial. Phase III rhIL-1ra Sepsis Syndrome Study Group. JAMA, Vol. 271, No. 23, (Jun 15), pp. (1836-1843), 0098-7484 (Print)

Fukumoto, L. R. \& Mazza, G. (2000). Assessing antioxidant and prooxidant activities of phenolic compounds. J Agric Food Chem, Vol. 48, No. 8, (Aug), pp. (3597-3604), 0021-8561 (Print)

Gao, X., Xu, Y. X., Janakiraman, N., Chapman, R. A. \& Gautam, S. C. (2001). Immunomodulatory activity of resveratrol: suppression of lymphocyte proliferation, development of cell-mediated cytotoxicity, and cytokine production. Biochem Pharmacol, Vol. 62, No. 9, (Nov 1), pp. (1299-1308), 0006-2952 (Print)

Geraets, L., Moonen, H. J., Brauers, K., Wouters, E. F., Bast, A. \& Hageman, G. J. (2007). Dietary flavones and flavonoles are inhibitors of poly(ADP-ribose)polymerase- 1 in pulmonary epithelial cells. J Nutr, Vol. 137, No. 10, (Oct), pp. (2190-2195), 0022-3166 (Print)

Gerhauser, C., Klimo, K., Heiss, E., Neumann, I., Gamal-Eldeen, A., Knauft, J., Liu, G. Y., Sitthimonchai, S. \& Frank, N. (2003). Mechanism-based in vitro screening of potential cancer chemopreventive agents. Mutat Res, Vol. 523-524, No. (Feb-Mar), pp. (163-172), 0027-5107 (Print)

Gomez-Jimenez, J., Salgado, A., Mourelle, M., Martin, M. C., Segura, R. M., Peracaula, R. \& Moncada, S. (1995). L-arginine: nitric oxide pathway in endotoxemia and human septic shock. Crit Care Med, Vol. 23, No. 2, (Feb), pp. (253-258), 0090-3493 (Print)

Gonthier, M. P., Rios, L. Y., Verny, M., Remesy, C. \& Scalbert, A. (2003). Novel liquid chromatography-electrospray ionization mass spectrometry method for the quantification in human urine of microbial aromatic acid metabolites derived from dietary polyphenols. J Chromatogr B Analyt Technol Biomed Life Sci, Vol. 789, No. 2, (Jun 15), pp. (247-255), 1570-0232 (Print)

Gonzales, A. M. \& Orlando, R. A. (2008). Curcumin and resveratrol inhibit nuclear factorkappaB-mediated cytokine expression in adipocytes. Nutr Metab (Lond), Vol. 5, No. pp. (17), 1743-7075 (Electronic)

Gradisar, H., Keber, M. M., Pristovsek, P. \& Jerala, R. (2007). MD-2 as the target of curcumin in the inhibition of response to LPS. J Leukoc Biol, Vol. 82, No. 4, (Oct), pp. (968-974), 0741-5400 (Print)

Gukovsky, I., Reyes, C. N., Vaquero, E. C., Gukovskaya, A. S. \& Pandol, S. J. (2003). Curcumin ameliorates ethanol and nonethanol experimental pancreatitis. Am J Physiol Gastrointest Liver Physiol, Vol. 284, No. 1, (Jan), pp. (G85-95), 0193-1857 (Print)

Gulcin, I. (2006). Antioxidant activity of caffeic acid (3,4-dihydroxycinnamic acid). Toxicology, Vol. 217, No. 2-3, (Jan 16), pp. (213-220), 0300-483X (Print)

Guo, Q., Zhao, B., Li, M., Shen, S. \& Xin, W. (1996). Studies on protective mechanisms of four components of green tea polyphenols against lipid peroxidation in synaptosomes. Biochim Biophys Acta, Vol. 1304, No. 3, (Dec 13), pp. (210-222), 00063002 (Print)

Hakkinen, S. H., Karenlampi, S. O., Heinonen, I. M., Mykkanen, H. M. \& Torronen, A. R. (1999). Content of the flavonols quercetin, myricetin, and kaempferol in 25 edible berries. J Agric Food Chem, Vol. 47, No. 6, (Jun), pp. (2274-2279), 0021-8561 (Print) 
Han, M. H., Yang, X. W., Zhong, G. Y. \& Zhang, M. (2007). [Bioactive constituents inhibiting TNF-alpha production in fresh rhizome of Pinellia ternata]. Zhongguo Zhong Yao Za Zhi, Vol. 32, No. 17, (Sep), pp. (1755-1759), 1001-5302 (Print)

Hanasaki, Y., Ogawa, S. \& Fukui, S. (1994). The correlation between active oxygens scavenging and antioxidative effects of flavonoids. Free Radic Biol Med, Vol. 16, No. 6, (Jun), pp. (845-850), 0891-5849 (Print)

Harada, M., Kan, Y., Naoki, H., Fukui, Y., Kageyama, N., Nakai, M., Miki, W. \& Kiso, Y. (1999). Identification of the major antioxidative metabolites in biological fluids of the rat with ingested (+)-catechin and (-)-epicatechin. Biosci Biotechnol Biochem, Vol. 63, No. 6, (Jun), pp. (973-977), 0916-8451 (Print)

Hatcher, H., Planalp, R., Cho, J., Torti, F. M. \& Torti, S. V. (2008). Curcumin: from ancient medicine to current clinical trials. Cell Mol Life Sci, Vol. 65, No. 11, (Jun), pp. (16311652), 1420-682X (Print)

Heijnen, C. G., Haenen, G. R., Vekemans, J. A. \& Bast, A. (2001). Peroxynitrite scavenging of flavonoids: structure activity relationship. Environ Toxicol Pharmacol, Vol. 10, No. 4, (Sep), pp. (199-206), 1382-6689 (Print)

Heuer, J. G., Sharma, G. R., Gerlitz, B., Zhang, T., Bailey, D. L., Ding, C., Berg, D. T., Perkins, D., Stephens, E. J., Holmes, K. C., Grubbs, R. L., Fynboe, K. A., Chen, Y. F., Grinnell, B. \& Jakubowski, J. A. (2004). Evaluation of protein C and other biomarkers as predictors of mortality in a rat cecal ligation and puncture model of sepsis. Crit Care Med, Vol. 32, No. 7, (Jul), pp. (1570-1578), 0090-3493 (Print)

Hidaka, H., Ishiko, T., Furuhashi, T., Kamohara, H., Suzuki, S., Miyazaki, M., Ikeda, O., Mita, S., Setoguchi, T. \& Ogawa, M. (2002). Curcumin inhibits interleukin 8 production and enhances interleukin 8 receptor expression on the cell surface:impact on human pancreatic carcinoma cell growth by autocrine regulation. Cancer, Vol. 95, No. 6, (Sep 15), pp. (1206-1214), 0008-543X (Print)

Hirata, A., Murakami, Y., Atsumi, T., Shoji, M., Ogiwara, T., Shibuya, K., Ito, S., Yokoe, I. \& Fujisawa, S. (2005). Ferulic acid dimer inhibits lipopolysaccharide-stimulated cyclooxygenase-2 expression in macrophages. In Vivo, Vol. 19, No. 5, (Sep-Oct), pp. (849-853), 0258-851X (Print)

Holmes-McNary, M. \& Baldwin, A. S., Jr. (2000). Chemopreventive properties of transresveratrol are associated with inhibition of activation of the IkappaB kinase. Cancer Res, Vol. 60, No. 13, (Jul 1), pp. (3477-3483), 0008-5472 (Print)

Hotchkiss, R. S., Chang, K. C., Swanson, P. E., Tinsley, K. W., Hui, J. J., Klender, P., Xanthoudakis, S., Roy, S., Black, C., Grimm, E., Aspiotis, R., Han, Y., Nicholson, D. W. \& Karl, I. E. (2000). Caspase inhibitors improve survival in sepsis: a critical role of the lymphocyte. Nat Immunol, Vol. 1, No. 6, (Dec), pp. (496-501), 1529-2908 (Print)

Hotchkiss, R. S. \& Karl, I. E. (2003). The pathophysiology and treatment of sepsis. N Engl J Med, Vol. 348, No. 2, (Jan 9), pp. (138-150), 1533-4406 (Electronic)

Hsu, C. H. \& Cheng, A. L. (2007). Clinical studies with curcumin. Adv Exp Med Biol, Vol. 595, No. pp. (471-480), 0065-2598 (Print)

Ichikawa, D., Matsui, A., Imai, M., Sonoda, Y. \& Kasahara, T. (2004). Effect of various catechins on the IL-12p40 production by murine peritoneal macrophages and a macrophage cell line, J774.1. Biol Pharm Bull, Vol. 27, No. 9, (Sep), pp. (1353-1358), 0918-6158 (Print)

Ireson, C., Orr, S., Jones, D. J., Verschoyle, R., Lim, C. K., Luo, J. L., Howells, L., Plummer, S., Jukes, R., Williams, M., Steward, W. P. \& Gescher, A. (2001). Characterization of 
metabolites of the chemopreventive agent curcumin in human and rat hepatocytes and in the rat in vivo, and evaluation of their ability to inhibit phorbol esterinduced prostaglandin E2 production. Cancer Res, Vol. 61, No. 3, (Feb 1), pp. (10581064), 0008-5472 (Print)

Jang, D. S., Kang, B. S., Ryu, S. Y., Chang, I. M., Min, K. R. \& Kim, Y. (1999). Inhibitory effects of resveratrol analogs on unopsonized zymosan-induced oxygen radical production. Biochem Pharmacol, Vol. 57, No. 6, (Mar 15), pp. (705-712), 0006-2952 (Print)

Jang, M., Cai, L., Udeani, G. O., Slowing, K. V., Thomas, C. F., Beecher, C. W., Fong, H. H., Farnsworth, N. R., Kinghorn, A. D., Mehta, R. G., Moon, R. C. \& Pezzuto, J. M. (1997). Cancer chemopreventive activity of resveratrol, a natural product derived from grapes. Science, Vol. 275, No. 5297, (Jan 10), pp. (218-220), 0036-8075 (Print)

Jeong, J. H., Kim, H. J., Lee, T. J., Kim, M. K., Park, E. S. \& Choi, B. S. (2004). Epigallocatechin 3-gallate attenuates neuronal damage induced by 3-hydroxykynurenine. Toxicology, Vol. 195, No. 1, (Jan 15), pp. (53-60), 0300-483X (Print)

Jiang, D., Chiaro, C., Maddali, P., Prabhu, K. S. \& Peterson, D. G. (2009). Identification of hydroxycinnamic acid-maillard reaction products in low-moisture baking model systems. J Agric Food Chem, Vol. 57, No. 21, (Nov 11), pp. (9932-9943), 1520-5118 (Electronic)

Jiang, Z., Mak, T. W., Sen, G. \& Li, X. (2004). Toll-like receptor 3-mediated activation of NFkappaB and IRF3 diverges at Toll-IL-1 receptor domain-containing adapter inducing IFN-beta. Proc Natl Acad Sci U S A, Vol. 101, No. 10, (Mar 9), pp. (35333538), 0027-8424 (Print)

Jin, C. Y., Lee, J. D., Park, C., Choi, Y. H. \& Kim, G. Y. (2007). Curcumin attenuates the release of pro-inflammatory cytokines in lipopolysaccharide-stimulated BV2 microglia. Acta Pharmacol Sin, Vol. 28, No. 10, (Oct), pp. (1645-1651), 1671-4083 (Print)

Jobin, C., Bradham, C. A., Russo, M. P., Juma, B., Narula, A. S., Brenner, D. A. \& Sartor, R. B. (1999). Curcumin blocks cytokine-mediated NF-kappa B activation and proinflammatory gene expression by inhibiting inhibitory factor I-kappa B kinase activity. J Immunol, Vol. 163, No. 6, (Sep 15), pp. (3474-3483), 0022-1767 (Print)

Joe, B. \& Lokesh, B. R. (1994). Role of capsaicin, curcumin and dietary n-3 fatty acids in lowering the generation of reactive oxygen species in rat peritoneal macrophages. Biochim Biophys Acta, Vol. 1224, No. 2, (Nov 10), pp. (255-263), 0006-3002 (Print)

Joe, B., Vijaykumar, M. \& Lokesh, B. R. (2004). Biological properties of curcumin-cellular and molecular mechanisms of action. Crit Rev Food Sci Nutr, Vol. 44, No. 2, pp. (97-111), 1040-8398 (Print)

Jung, W. J. \& Sung, M. K. (2004). Effects of major dietary antioxidants on inflammatory markers of RAW 264.7 macrophages. Biofactors, Vol. 21, No. 1-4, pp. (113-117), 09516433 (Print)

Jung, W. K., Choi, I., Lee, D. Y., Yea, S. S., Choi, Y. H., Kim, M. M., Park, S. G., Seo, S. K., Lee, S. W., Lee, C. M., Park, Y. M. \& Choi, I. W. (2008). Caffeic acid phenethyl ester protects mice from lethal endotoxin shock and inhibits lipopolysaccharide-induced cyclooxygenase-2 and inducible nitric oxide synthase expression in RAW 264.7 macrophages via the p38/ERK and NF-kappaB pathways. Int J Biochem Cell Biol, Vol. 40, No. 11, pp. (2572-2582), 1357-2725 (Print) 
Kabarowski, J. H., Zhu, K., Le, L. Q., Witte, O. N. \& Xu, Y. (2001). Lysophosphatidylcholine as a ligand for the immunoregulatory receptor G2A. Science, Vol. 293, No. 5530, (Jul 27), pp. (702-705), 0036-8075 (Print)

Kalyanaraman, B., Premovic, P. I. \& Sealy, R. C. (1987). Semiquinone anion radicals from addition of amino acids, peptides, and proteins to quinones derived from oxidation of catechols and catecholamines. An ESR spin stabilization study. J Biol Chem, Vol. 262, No. 23, (Aug 15), pp. (11080-11087), 0021-9258 (Print)

Kaneider, N. C., Mosheimer, B., Reinisch, N., Patsch, J. R. \& Wiedermann, C. J. (2004). Inhibition of thrombin-induced signaling by resveratrol and quercetin: effects on adenosine nucleotide metabolism in endothelial cells and platelet-neutrophil interactions. Thromb Res, Vol. 114, No. 3, pp. (185-194), 0049-3848 (Print)

Karin, M., Yamamoto, Y. \& Wang, Q. M. (2004). The IKK NF-kappa B system: a treasure trove for drug development. Nat Rev Drug Discov, Vol. 3, No. 1, (Jan), pp. (17-26), 1474-1776 (Print)

Kaur, G., Tirkey, N., Bharrhan, S., Chanana, V., Rishi, P. \& Chopra, K. (2006). Inhibition of oxidative stress and cytokine activity by curcumin in amelioration of endotoxininduced experimental hepatoxicity in rodents. Clin Exp Immunol, Vol. 145, No. 2, (Aug), pp. (313-321), 0009-9104 (Print)

Kawada, N., Seki, S., Inoue, M. \& Kuroki, T. (1998). Effect of antioxidants, resveratrol, quercetin, and $\mathrm{N}$-acetylcysteine, on the functions of cultured rat hepatic stellate cells and Kupffer cells. Hepatology, Vol. 27, No. 5, (May), pp. (1265-1274), 0270-9139 (Print)

Kempuraj, D., Madhappan, B., Christodoulou, S., Boucher, W., Cao, J., Papadopoulou, N., Cetrulo, C. L. \& Theoharides, T. C. (2005). Flavonols inhibit proinflammatory mediator release, intracellular calcium ion levels and protein kinase $C$ theta phosphorylation in human mast cells. Br J Pharmacol, Vol. 145, No. 7, (Aug), pp. (934-944), 0007-1188 (Print)

Kerry, N. \& Rice-Evans, C. (1998). Peroxynitrite oxidises catechols to o-quinones. FEBS Lett, Vol. 437, No. 3, (Oct 23), pp. (167-171), 0014-5793 (Print)

Khokhar, S. \& Magnusdottir, S. G. (2002). Total phenol, catechin, and caffeine contents of teas commonly consumed in the United kingdom. J Agric Food Chem, Vol. 50, No. 3, (Jan 30), pp. (565-570), 0021-8561 (Print)

Kim, I. B., Kim, D. Y., Lee, S. J., Sun, M. J., Lee, M. S., Li, H., Cho, J. J. \& Park, C. S. (2006). Inhibition of IL-8 production by green tea polyphenols in human nasal fibroblasts and A549 epithelial cells. Biol Pharm Bull, Vol. 29, No. 6, (Jun), pp. (1120-1125), 13475215 (Electronic)

Kim, N. Y., Pae, H. O., Ko, Y. S., Yoo, J. C., Choi, B. M., Jun, C. D., Chung, H. T., Inagaki, M., Higuchi, R. \& Kim, Y. C. (1999). In vitro inducible nitric oxide synthesis inhibitory active constituents from Fraxinus rhynchophylla. Planta Med, Vol. 65, No. 7, (Oct), pp. (656-658), 0032-0943 (Print)

Kim, O. K., Murakami, A., Nakamura, Y. \& Ohigashi, H. (1998). Screening of edible Japanese plants for nitric oxide generation inhibitory activities in RAW 264.7 cells. Cancer Lett, Vol. 125, No. 1-2, (Mar 13), pp. (199-207), 0304-3835 (Print)

Kobuchi, H., Droy-Lefaix, M. T., Christen, Y. \& Packer, L. (1997). Ginkgo biloba extract (EGb 761): inhibitory effect on nitric oxide production in the macrophage cell line RAW 264.7. Biochem Pharmacol, Vol. 53, No. 6, (Mar 21), pp. (897-903), 0006-2952 (Print) 
Koltuksuz, U., Ozen, S., Uz, E., Aydinc, M., Karaman, A., Gultek, A., Akyol, O., Gursoy, M. H. \& Aydin, E. (1999). Caffeic acid phenethyl ester prevents intestinal reperfusion injury in rats. J Pediatr Surg, Vol. 34, No. 10, (Oct), pp. (1458-1462), 0022-3468 (Print)

Kong, A. N., Yu, R., Chen, C., Mandlekar, S. \& Primiano, T. (2000). Signal transduction events elicited by natural products: role of MAPK and caspase pathways in homeostatic response and induction of apoptosis. Arch Pharm Res, Vol. 23, No. 1, (Feb), pp. (1-16), 0253-6269 (Print)

Kowalski, J., Samojedny, A., Paul, M., Pietsz, G. \& Wilczok, T. (2005). Effect of apigenin, kaempferol and resveratrol on the expression of interleukin-1beta and tumor necrosis factor-alpha genes in J774.2 macrophages. Pharmacol Rep, Vol. 57, No. 3, (May-Jun), pp. (390-394), 1734-1140 (Print)

Kundu, J. K., Shin, Y. K., Kim, S. H. \& Surh, Y. J. (2006). Resveratrol inhibits phorbol esterinduced expression of COX-2 and activation of NF-kappaB in mouse skin by blocking IkappaB kinase activity. Carcinogenesis, Vol. 27, No. 7, (Jul), pp. (14651474), 0143-3334 (Print)

Labinskyy, N., Csiszar, A., Veress, G., Stef, G., Pacher, P., Oroszi, G., Wu, J. \& Ungvari, Z. (2006). Vascular dysfunction in aging: potential effects of resveratrol, an antiinflammatory phytoestrogen. Curr Med Chem, Vol. 13, No. 9, pp. (989-996), 09298673 (Print)

Lee, J. J., Huang, W. T., Shao, D. Z., Liao, J. F. \& Lin, M. T. (2003). Blocking NF-kappaB activation may be an effective strategy in the fever therapy. Jpn J Physiol, Vol. 53, No. 5, (Oct), pp. (367-375), 0021-521X (Print)

Lee, M. J., Wang, Z. Y., Li, H., Chen, L., Sun, Y., Gobbo, S., Balentine, D. A. \& Yang, C. S. (1995). Analysis of plasma and urinary tea polyphenols in human subjects. Cancer Epidemiol Biomarkers Prev, Vol. 4, No. 4, (Jun), pp. (393-399), 1055-9965 (Print)

Leiro, J., Alvarez, E., Arranz, J. A., Laguna, R., Uriarte, E. \& Orallo, F. (2004). Effects of cisresveratrol on inflammatory murine macrophages: antioxidant activity and downregulation of inflammatory genes. J Leukoc Biol, Vol. 75, No. 6, (Jun), pp. (11561165), 0741-5400 (Print)

Levites, Y., Weinreb, O., Maor, G., Youdim, M. B. \& Mandel, S. (2001). Green tea polyphenol (-)-epigallocatechin-3-gallate prevents N-methyl-4-phenyl-1,2,3,6tetrahydropyridine-induced dopaminergic neurodegeneration. J Neurochem, Vol. 78, No. 5, (Sep), pp. (1073-1082), 0022-3042 (Print)

Levites, Y., Youdim, M. B., Maor, G. \& Mandel, S. (2002). Attenuation of 6hydroxydopamine (6-OHDA)-induced nuclear factor-kappaB (NF-kappaB) activation and cell death by tea extracts in neuronal cultures. Biochem Pharmacol, Vol. 63, No. 1, (Jan 1), pp. (21-29), 0006-2952 (Print)

Lewis, T. S., Shapiro, P. S. \& Ahn, N. G. (1998). Signal transduction through MAP kinase cascades. Adv Cancer Res, Vol. 74, No. pp. (49-139), 0065-230X (Print)

Li, W., Ashok, M., Li, J., Yang, H., Sama, A. E. \& Wang, H. (2007). A major ingredient of green tea rescues mice from lethal sepsis partly by inhibiting HMGB1. PLoS One, Vol. 2, No. 11, pp. (e1153), 1932-6203 (Electronic)

Li, Y. \& Sarkar, F. H. (2002). Inhibition of nuclear factor kappaB activation in PC3 cells by genistein is mediated via Akt signaling pathway. Clin Cancer Res, Vol. 8, No. 7, (Jul), pp. (2369-2377), 1078-0432 (Print) 
Liacini, A., Sylvester, J., Li, W. Q., Huang, W., Dehnade, F., Ahmad, M. \& Zafarullah, M. (2003). Induction of matrix metalloproteinase-13 gene expression by TNF-alpha is mediated by MAP kinases, AP-1, and NF-kappaB transcription factors in articular chondrocytes. Exp Cell Res, Vol. 288, No. 1, (Aug 1), pp. (208-217), 0014-4827 (Print)

Lin, Y. L. \& Lin, J. K. (1997). (-)-Epigallocatechin-3-gallate blocks the induction of nitric oxide synthase by down-regulating lipopolysaccharide-induced activity of transcription factor nuclear factor-kappaB. Mol Pharmacol, Vol. 52, No. 3, (Sep), pp. (465-472), 0026-895X (Print)

Lin, Y. L., Tsai, S. H., Lin-Shiau, S. Y., Ho, C. T. \& Lin, J. K. (1999). Theaflavin-3,3'-digallate from black tea blocks the nitric oxide synthase by down-regulating the activation of NF-kappaB in macrophages. Eur J Pharmacol, Vol. 367, No. 2-3, (Feb 19), pp. (379388), 0014-2999 (Print)

Lu, L. H., Lee, S. S. \& Huang, H. C. (1998). Epigallocatechin suppression of proliferation of vascular smooth muscle cells: correlation with c-jun and JNK. Br J Pharmacol, Vol. 124, No. 6, (Jul), pp. (1227-1237), 0007-1188 (Print)

Ma, Z., Wei, X., Fontanilla, C., Noelker, C., Dodel, R., Hampel, H. \& Du, Y. (2006). Caffeic acid phenethyl ester blocks free radical generation and 6-hydroxydopamineinduced neurotoxicity. Life Sci, Vol. 79, No. 13, (Aug 22), pp. (1307-1311), 0024-3205 (Print)

Manach, C., Scalbert, A., Morand, C., Remesy, C. \& Jimenez, L. (2004). Polyphenols: food sources and bioavailability. Am J Clin Nutr, Vol. 79, No. 5, (May), pp. (727-747), 0002-9165 (Print)

Manjeet, K. R. \& Ghosh, B. (1999). Quercetin inhibits LPS-induced nitric oxide and tumor necrosis factor-alpha production in murine macrophages Int J Immunopharmacol, Vol.21, No. 7, (Jul), pp. (435-443)

Manna, S. K., Mukhopadhyay, A. \& Aggarwal, B. B. (2000). Resveratrol suppresses TNFinduced activation of nuclear transcription factors NF-kappa B, activator protein-1, and apoptosis: potential role of reactive oxygen intermediates and lipid peroxidation. J Immunol, Vol. 164, No. 12, (Jun 15), pp. (6509-6519), 0022-1767 (Print)

Marquez, N., Sancho, R., Macho, A., Calzado, M. A., Fiebich, B. L. \& Munoz, E. (2004). Caffeic acid phenethyl ester inhibits T-cell activation by targeting both nuclear factor of activated T-cells and NF-kappaB transcription factors. J Pharmacol Exp Ther, Vol. 308, No. 3, (Mar), pp. (993-1001), 0022-3565 (Print)

Martinez, J. \& Moreno, J. J. (2000). Effect of resveratrol, a natural polyphenolic compound, on reactive oxygen species and prostaglandin production. Biochem Pharmacol, Vol. 59, No. 7, (Apr 1), pp. (865-870), 0006-2952 (Print)

Mateo Anson, N., Aura, A. M., Selinheimo, E., Mattila, I., Poutanen, K., van den Berg, R., Havenaar, R., Bast, A. \& Haenen, G. R. (2011). Bioprocessing of wheat bran in whole wheat bread increases the bioavailability of phenolic acids in men and exerts antiinflammatory effects ex vivo. J Nutr, Vol. 141, No. 1, (Jan), pp. (137-143), 15416100 (Electronic)

Mattila, P. \& Kumpulainen, J. (2002). Determination of free and total phenolic acids in plantderived foods by HPLC with diode-array detection. J Agric Food Chem, Vol. 50, No. 13, (Jun 19), pp. (3660-3667), 0021-8561 (Print) 
Miles, E. A., Zoubouli, P. \& Calder, P. C. (2005). Differential anti-inflammatory effects of phenolic compounds from extra virgin olive oil identified in human whole blood cultures. Nutrition, Vol. 21, No. 3, (Mar), pp. (389-394), 0899-9007 (Print)

Miriyala, S., Panchatcharam, M. \& Rengarajulu, P. (2007). Cardioprotective effects of curcumin. Adv Exp Med Biol, Vol. 595, No. pp. (359-377), 0065-2598 (Print)

Monks, T. J. \& Lau, S. S. (1992). Toxicology of quinone-thioethers. Crit Rev Toxicol, Vol. 22, No. 5-6, pp. (243-270), 1040-8444 (Print)

Nair, M. P., Mahajan, S., Reynolds, J. L., Aalinkeel, R., Nair, H., Schwartz, S. A. \& Kandaswami, C. (2006). The flavonoid quercetin inhibits proinflammatory cytokine (tumor necrosis factor alpha) gene expression in normal peripheral blood mononuclear cells via modulation of the NF-kappa beta system. Clin Vaccine Immunol, Vol. 13, No. 3, (Mar), pp. (319-328), 1556-6811 (Print)

Nakagawa, K., Okuda, S. \& Miyazawa, T. (1997). Dose-dependent incorporation of tea catechins, (-)-epigallocatechin-3-gallate and (-)-epigallocatechin, into human plasma. Biosci Biotechnol Biochem, Vol. 61, No. 12, (Dec), pp. (1981-1985), 0916-8451 (Print)

Nanjo, F., Goto, K., Seto, R., Suzuki, M., Sakai, M. \& Hara, Y. (1996). Scavenging effects of tea catechins and their derivatives on 1,1-diphenyl-2-picrylhydrazyl radical. Free Radic Biol Med, Vol. 21, No. 6, pp. (895-902), 0891-5849 (Print)

Natarajan, K., Singh, S., Burke, T. R., Jr., Grunberger, D. \& Aggarwal, B. B. (1996). Caffeic acid phenethyl ester is a potent and specific inhibitor of activation of nuclear transcription factor NF-kappa B. Proc Natl Acad Sci U S A, Vol. 93, No. 17, (Aug 20), pp. (9090-9095), 0027-8424 (Print)

Nenadis, N., Zhang, H. Y. \& Tsimidou, M. Z. (2003). Structure-antioxidant activity relationship of ferulic acid derivatives: effect of carbon side chain characteristic groups. J Agric Food Chem, Vol. 51, No. 7, (Mar 26), pp. (1874-1879), 0021-8561 (Print)

Netsch, M. I., Gutmann, H., Aydogan, C. \& Drewe, J. (2006). Green tea extract induces interleukin-8 (IL-8) mRNA and protein expression but specifically inhibits IL-8 secretion in caco-2 cells. Planta Med, Vol. 72, No. 8, (Jun), pp. (697-702), 0032-0943 (Print)

Okabe, S., Fujimoto, N., Sueoka, N., Suganuma, M. \& Fujiki, H. (2001). Modulation of gene expression by (-)-epigallocatechin gallate in PC-9 cells using a cDNA expression array. Biol Pharm Bull, Vol. 24, No. 8, (Aug), pp. (883-886), 0918-6158 (Print)

Okutan, H., Ozcelik, N., Yilmaz, H. R. \& Uz, E. (2005). Effects of caffeic acid phenethyl ester on lipid peroxidation and antioxidant enzymes in diabetic rat heart. Clin Biochem, Vol. 38, No. 2, (Feb), pp. (191-196), 0009-9120 (Print)

O'Leary, K. A., de Pascual-Tereasa, S., Needs, P. W., Bao, Y. P., O'Brien, N. M. \& Williamson, G. (2004). Effect of flavonoids and vitamin E on cyclooxygenase-2 (COX-2) transcription. Mutat Res, Vol. 551, No. 1-2, (Jul 13), pp. (245-254), 0027-5107 (Print)

Osuchowski, M. F., Welch, K., Siddiqui, J. \& Remick, D. G. (2006). Circulating cytokine/inhibitor profiles reshape the understanding of the SIRS/CARS continuum in sepsis and predict mortality. J Immunol, Vol. 177, No. 3, (Aug 1), pp. (1967-1974), 0022-1767 (Print)

Ouyang, P., Peng, W. L., Xu, D. L., Lai, W. Y. \& Xu, A. L. (2004). Green tea polyphenols inhibit advanced glycation end product-induced rat vascular smooth muscle cell 
proliferation. Di Yi Jun Yi Da Xue Xue Bao, Vol. 24, No. 3, (Mar), pp. (247-251), 10002588 (Print)

Pan, M. H., Lin-Shiau, S. Y. \& Lin, J. K. (2000). Comparative studies on the suppression of nitric oxide synthase by curcumin and its hydrogenated metabolites through down-regulation of IkappaB kinase and NFkappaB activation in macrophages. Biochem Pharmacol, Vol. 60, No. 11, (Dec 1), pp. (1665-1676), 0006-2952 (Print)

Pannala, A. S., Rice-Evans, C. A., Halliwell, B. \& Singh, S. (1997). Inhibition of peroxynitritemediated tyrosine nitration by catechin polyphenols. Biochem Biophys Res Commun, Vol. 232, No. 1, (Mar 6), pp. (164-168), 0006-291X (Print)

Parrish, W. R., Gallowitsch-Puerta, M., Czura, C. J. \& Tracey, K. J. (2008). Experimental therapeutic strategies for severe sepsis: mediators and mechanisms. Ann NY Acad Sci, Vol. 1144, No. (Nov), pp. (210-236), 1749-6632 (Electronic)

Pattanaik, U. \& Prasad, K. (1996). Endotoxemia and oxidative stress. Ann N Y Acad Sci, Vol. 793, No. (Sep 30), pp. (506-510), 0077-8923 (Print)

Pearson, K. J., Baur, J. A., Lewis, K. N., Peshkin, L., Price, N. L., Labinskyy, N., Swindell, W. R., Kamara, D., Minor, R. K., Perez, E., Jamieson, H. A., Zhang, Y., Dunn, S. R., Sharma, K., Pleshko, N., Woollett, L. A., Csiszar, A., Ikeno, Y., Le Couteur, D., Elliott, P. J., Becker, K. G., Navas, P., Ingram, D. K., Wolf, N. S., Ungvari, Z., Sinclair, D. A. \& de Cabo, R. (2008). Resveratrol delays age-related deterioration and mimics transcriptional aspects of dietary restriction without extending life span. Cell Metab, Vol. 8, No. 2, (Aug), pp. (157-168), 1932-7420 (Electronic)

Peet, G. W. \& Li, J. (1999). IkappaB kinases alpha and beta show a random sequential kinetic mechanism and are inhibited by staurosporine and quercetin. J Biol Chem, Vol. 274, No. 46, (Nov 12), pp. (32655-32661), 0021-9258 (Print)

Pietta, P. G., Simonetti, P., Gardana, C., Brusamolino, A., Morazzoni, P. \& Bombardelli, E. (1998). Catechin metabolites after intake of green tea infusions. Biofactors, Vol. 8, No. 1-2, pp. (111-118), 0951-6433 (Print)

Plummer, S. M., Holloway, K. A., Manson, M. M., Munks, R. J., Kaptein, A., Farrow, S. \& Howells, L. (1999). Inhibition of cyclo-oxygenase 2 expression in colon cells by the chemopreventive agent curcumin involves inhibition of NF-kappaB activation via the NIK/IKK signalling complex. Oncogene, Vol. 18, No. 44, (Oct 28), pp. (60136020), 0950-9232 (Print)

Porath, D., Riegger, C., Drewe, J. \& Schwager, J. (2005). Epigallocatechin-3-gallate impairs chemokine production in human colon epithelial cell lines. J Pharmacol Exp Ther, Vol. 315, No. 3, (Dec), pp. (1172-1180), 0022-3565 (Print)

Psotova, J., Lasovsky, J. \& Vicar, J. (2003). Metal-chelating properties, electrochemical behavior, scavenging and cytoprotective activities of six natural phenolics. Biomed Pap Med Fac Univ Palacky Olomouc Czech Repub, Vol. 147, No. 2, (Dec), pp. (147-153), 1213-8118 (Print)

Radnai, B., Tucsek, Z., Bognar, Z., Antus, C., Mark, L., Berente, Z., Gallyas, F., Jr., Sumegi, B. \& Veres, B. (2009). Ferulaldehyde, a water-soluble degradation product of polyphenols, inhibits the lipopolysaccharide-induced inflammatory response in mice. J Nutr, Vol. 139, No. 2, (Feb), pp. (291-297), 1541-6100 (Electronic)

Rahman, I., Biswas, S. K. \& Kirkham, P. A. (2006). Regulation of inflammation and redox signaling by dietary polyphenols. Biochem Pharmacol, Vol. 72, No. 11, (Nov 30), pp. (1439-1452), 0006-2952 (Print) 
Rahman, I., Marwick, J. \& Kirkham, P. (2004). Redox modulation of chromatin remodeling: impact on histone acetylation and deacetylation, NF-kappaB and pro-inflammatory gene expression. Biochem Pharmacol, Vol. 68, No. 6, (Sep 15), pp. (1255-1267), 00062952 (Print)

Reddy, A. C. \& Lokesh, B. R. (1992). Studies on spice principles as antioxidants in the inhibition of lipid peroxidation of rat liver microsomes. Mol Cell Biochem, Vol. 111, No. 1-2, (Apr), pp. (117-124), 0300-8177 (Print)

Rehman, M. U. \& Sultana, S. (2011). Attenuation of oxidative stress, inflammation and early markers of tumor promotion by caffeic acid in Fe-NTA exposed kidneys of Wistar rats. Mol Cell Biochem, pp. 1573-4919 (Electronic)

Rios, L. Y., Gonthier, M. P., Remesy, C., Mila, I., Lapierre, C., Lazarus, S. A., Williamson, G. \& Scalbert, A. (2003). Chocolate intake increases urinary excretion of polyphenolderived phenolic acids in healthy human subjects. Am J Clin Nutr, Vol. 77, No. 4, (Apr), pp. (912-918), 0002-9165 (Print)

Romashkova, J. A. \& Makarov, S. S. (1999). NF-kappaB is a target of AKT in anti-apoptotic PDGF signalling. Nature, Vol. 401, No. 6748, (Sep 2), pp. (86-90), 0028-0836 (Print)

Ronchetti, D., Borghi, V., Gaitan, G., Herrero, J. F. \& Impagnatiello, F. (2009). NCX 2057, a novel NO-releasing derivative of ferulic acid, suppresses inflammatory and nociceptive responses in in vitro and in vivo models. Br J Pharmacol, Vol. 158, No. 2, (Sep), pp. (569-579), 1476-5381 (Electronic)

Rotondo, S., Rajtar, G., Manarini, S., Celardo, A., Rotillo, D., de Gaetano, G., Evangelista, V. \& Cerletti, C. (1998). Effect of trans-resveratrol, a natural polyphenolic compound, on human polymorphonuclear leukocyte function. Br J Pharmacol, Vol. 123, No. 8, (Apr), pp. (1691-1699), 0007-1188 (Print)

Salah, N., Miller, N. J., Paganga, G., Tijburg, L., Bolwell, G. P. \& Rice-Evans, C. (1995). Polyphenolic flavanols as scavengers of aqueous phase radicals and as chainbreaking antioxidants. Arch Biochem Biophys, Vol. 322, No. 2, (Oct 1), pp. (339-346), 0003-9861 (Print)

Sanchez-Fidalgo, S., Cardeno, A., Villegas, I., Talero, E. \& de la Lastra, C. A. (2010). Dietary supplementation of resveratrol attenuates chronic colonic inflammation in mice. Eur J Pharmacol, Vol. 633, No. 1-3, (May 10), pp. (78-84), 1879-0712 (Electronic)

Sato, Y., Yuasa, Y., Abe, Y. \& Akagawa, Y. (1995). Finite element and Weibull analysis to estimate failure risk in resin-bonded retainers. Int J Prosthodont, Vol. 8, No. 1, (JanFeb), pp. (73-78), 0893-2174 (Print)

Scumpia, P. O. \& Moldawer, L. L. (2005). Biology of interleukin-10 and its regulatory roles in sepsis syndromes. Crit Care Med, Vol. 33, No. 12 Suppl, (Dec), pp. (S468-471), 00903493 (Print)

Sharma, R. A., Euden, S. A., Platton, S. L., Cooke, D. N., Shafayat, A., Hewitt, H. R., Marczylo, T. H., Morgan, B., Hemingway, D., Plummer, S. M., Pirmohamed, M., Gescher, A. J. \& Steward, W. P. (2004). Phase I clinical trial of oral curcumin: biomarkers of systemic activity and compliance. Clin Cancer Res, Vol. 10, No. 20, (Oct 15), pp. (6847-6854), 1078-0432 (Print)

Sharma, S., Chopra, K., Kulkarni, S. K. \& Agrewala, J. N. (2007). Resveratrol and curcumin suppress immune response through CD28/CTLA-4 and CD80 co-stimulatory pathway. Clin Exp Immunol, Vol. 147, No. 1, (Jan), pp. (155-163), 0009-9104 (Print) 
Shen, S. Q., Zhang, Y., Xiang, J. J. \& Xiong, C. L. (2007). Protective effect of curcumin against liver warm ischemia/reperfusion injury in rat model is associated with regulation of heat shock protein and antioxidant enzymes. World J Gastroenterol, Vol. 13, No. 13, (Apr 7), pp. (1953-1961), 1007-9327 (Print)

Shin, H. Y., Kim, S. H., Jeong, H. J., Kim, S. Y., Shin, T. Y., Um, J. Y., Hong, S. H. \& Kim, H. M. (2007). Epigallocatechin-3-gallate inhibits secretion of TNF-alpha, IL-6 and IL-8 through the attenuation of ERK and NF-kappaB in HMC-1 cells. Int Arch Allergy Immunol, Vol. 142, No. 4, pp. (335-344), 1018-2438 (Print)

Singh, S. \& Aggarwal, B. B. (1995). Activation of transcription factor NF-kappa B is suppressed by curcumin (diferuloylmethane) [corrected]. J Biol Chem, Vol. 270, No. 42, (Oct 20), pp. (24995-25000), 0021-9258 (Print)

Soleas, G. J., Diamandis, E. P. \& Goldberg, D. M. (1997). Resveratrol: a molecule whose time has come? And gone? Clin Biochem, Vol. 30, No. 2, (Mar), pp. (91-113), 0009-9120 (Print)

Soobrattee, M. A., Neergheen, V. S., Luximon-Ramma, A., Aruoma, O. I. \& Bahorun, T. (2005). Phenolics as potential antioxidant therapeutic agents: mechanism and actions. Mutat Res, Vol. 579, No. 1-2, (Nov 11), pp. (200-213), 0027-5107 (Print)

Srinivasan, M., Sudheer, A. R. \& Menon, V. P. (2007). Ferulic Acid: therapeutic potential through its antioxidant property. J Clin Biochem Nutr, Vol. 40, No. 2, (Mar), pp. (92100), 0912-0009 (Print)

Subbaramaiah, K., Chung, W. J., Michaluart, P., Telang, N., Tanabe, T., Inoue, H., Jang, M., Pezzuto, J. M. \& Dannenberg, A. J. (1998). Resveratrol inhibits cyclooxygenase-2 transcription and activity in phorbol ester-treated human mammary epithelial cells. J Biol Chem, Vol. 273, No. 34, (Aug 21), pp. (21875-21882), 0021-9258 (Print)

Suganuma, M., Okabe, S., Oniyama, M., Tada, Y., Ito, H. \& Fujiki, H. (1998). Wide distribution of $[3 \mathrm{H}](-)$-epigallocatechin gallate, a cancer preventive tea polyphenol, in mouse tissue. Carcinogenesis, Vol. 19, No. 10, (Oct), pp. (1771-1776), 0143-3334 (Print)

Tang, F. Y., Nguyen, N. \& Meydani, M. (2003). Green tea catechins inhibit VEGF-induced angiogenesis in vitro through suppression of VE-cadherin phosphorylation and inactivation of Akt molecule. Int J Cancer, Vol. 106, No. 6, (Oct 10), pp. (871-878), 0020-7136 (Print)

Tayman, C., Tonbul, A., Kosus, A., Hirfanoglu, I. M., Haltas, H., Uysal, S., Tatli, M. M. \& Andiran, F. (2011). Protective effects of caffeic acid phenethyl ester (CAPE) on intestinal damage in necrotizing enterocolitis. Pediatr Surg Int, Vol. No. (Jun 28), pp. 1437-9813 (Electronic)

Tedeschi, E., Menegazzi, M., Yao, Y., Suzuki, H., Forstermann, U. \& Kleinert, H. (2004). Green tea inhibits human inducible nitric-oxide synthase expression by downregulating signal transducer and activator of transcription-1alpha activation. Mol Pharmacol, Vol. 65, No. 1, (Jan), pp. (111-120), 0026-895X (Print)

Tracey, K. J. \& Cerami, A. (1993). Tumor necrosis factor, other cytokines and disease. Annu Rev Cell Biol, Vol. 9, No. pp. (317-343), 0743-4634 (Print)

Tracey, K. J. \& Cerami, A. (1994). Tumor necrosis factor: a pleiotropic cytokine and therapeutic target. Annu Rev Med, Vol. 45, No. pp. (491-503), 0066-4219 (Print)

Tucsek, Z., Radnai, B., Racz, B., Debreceni, B., Priber, J. K., Dolowschiak, T., Palkovics, T., Gallyas, F., Jr., Sumegi, B. \& Veres, B. (2011). Suppressing LPS-induced early signal 
transduction in macrophages by a polyphenol degradation product: a critical role of MKP-1. J Leukoc Biol, Vol. 89, No. 1, (Jan), pp. (105-111), 1938-3673 (Electronic)

van Acker, S. A., Tromp, M. N., Haenen, G. R., van der Vijgh, W. J. \& Bast, A. (1995). Flavonoids as scavengers of nitric oxide radical. Biochem Biophys Res Commun, Vol. 214, No. 3, (Sep 25), pp. (755-759), 0006-291X (Print)

van der Poll, T. \& Lowry, S. F. (1995). Tumor necrosis factor in sepsis: mediator of multiple organ failure or essential part of host defense? Shock, Vol. 3, No. 1, (Jan), pp. (1-12), 1073-2322 (Print)

Veres, B., Radnai, B., Gallyas, F., Jr., Varbiro, G., Berente, Z., Osz, E. \& Sumegi, B. (2004). Regulation of kinase cascades and transcription factors by a poly(ADP-ribose) polymerase-1 inhibitor, 4-hydroxyquinazoline, in lipopolysaccharide-induced inflammation in mice. J Pharmacol Exp Ther, Vol. 310, No. 1, (Jul), pp. (247-255), 0022-3565 (Print)

Victor, V. M., Rocha, M., Esplugues, J. V. \& De la Fuente, M. (2005). Role of free radicals in sepsis: antioxidant therapy. Curr Pharm Des, Vol. 11, No. 24, pp. (3141-3158), 13816128 (Print)

Vitrac, X., Desmouliere, A., Brouillaud, B., Krisa, S., Deffieux, G., Barthe, N., Rosenbaum, J. \& Merillon, J. M. (2003). Distribution of [14C]-trans-resveratrol, a cancer chemopreventive polyphenol, in mouse tissues after oral administration. Life Sci, Vol. 72, No. 20, (Apr 4), pp. (2219-2233), 0024-3205 (Print)

Wadsworth, T. L., McDonald, T. L. \& Koop, D. R. (2001). Effects of Ginkgo biloba extract (EGb 761) and quercetin on lipopolysaccharide-induced signaling pathways involved in the release of tumor necrosis factor-alpha. Biochem Pharmacol, Vol. 62, No. 7, (Oct 1), pp. (963-974), 0006-2952 (Print)

Weisberg, S. P., Leibel, R. \& Tortoriello, D. V. (2008). Dietary curcumin significantly improves obesity-associated inflammation and diabetes in mouse models of diabesity. Endocrinology, Vol. 149, No. 7, (Jul), pp. (3549-3558), 0013-7227 (Print)

Weisburger, J. H. \& Chung, F. L. (2002). Mechanisms of chronic disease causation by nutritional factors and tobacco products and their prevention by tea polyphenols. Food Chem Toxicol, Vol. 40, No. 8, (Aug), pp. (1145-1154), 0278-6915 (Print)

Wenzel, E., Soldo, T., Erbersdobler, H. \& Somoza, V. (2005). Bioactivity and metabolism of trans-resveratrol orally administered to Wistar rats. Mol Nutr Food Res, Vol. 49, No. 5, (May), pp. (482-494), 1613-4125 (Print)

Wenzel, E. \& Somoza, V. (2005). Metabolism and bioavailability of trans-resveratrol. Mol Nutr Food Res, Vol. 49, No. 5, (May), pp. (472-481), 1613-4125 (Print)

Wheeler, D. S., Catravas, J. D., Odoms, K., Denenberg, A., Malhotra, V. \& Wong, H. R. (2004). Epigallocatechin-3-gallate, a green tea-derived polyphenol, inhibits IL-1 beta-dependent proinflammatory signal transduction in cultured respiratory epithelial cells. J Nutr, Vol. 134, No. 5, (May), pp. (1039-1044), 0022-3166 (Print)

Wiseman, S., Mulder, T. \& Rietveld, A. (2001). Tea flavonoids: bioavailability in vivo and effects on cell signaling pathways in vitro. Antioxid Redox Signal, Vol. 3, No. 6, (Dec), pp. (1009-1021), 1523-0864 (Print)

Wu, C. T., Yu, H. P., Chung, C. Y., Lau, Y. T. \& Liao, S. K. (2008). Attenuation of lung inflammation and pro-inflammatory cytokine production by resveratrol following trauma-hemorrhage. Chin J Physiol, Vol. 51, No. 6, (Dec 31), pp. (363-368), 0304-4920 (Print) 
Yang, F., de Villiers, W. J., McClain, C. J. \& Varilek, G. W. (1998). Green tea polyphenols block endotoxin-induced tumor necrosis factor-production and lethality in a murine model. J Nutr, Vol. 128, No. 12, (Dec), pp. (2334-2340), 0022-3166 (Print)

Yang, F., Oz, H. S., Barve, S., de Villiers, W. J., McClain, C. J. \& Varilek, G. W. (2001). The green tea polyphenol (-)-epigallocatechin-3-gallate blocks nuclear factor-kappa B activation by inhibiting I kappa B kinase activity in the intestinal epithelial cell line IEC-6. Mol Pharmacol, Vol. 60, No. 3, (Sep), pp. (528-533), 0026-895X (Print)

Yildiz, Y., Serter, M., Ek, R. O., Ergin, K., Cecen, S., Demir, E. M. \& Yenisey, C. (2009). Protective effects of caffeic acid phenethyl ester on intestinal ischemia-reperfusion injury. Dig Dis Sci, Vol. 54, No. 4, (Apr), pp. (738-744), 1573-2568 (Electronic)

Yilmaz, H. R., Uz, E., Yucel, N., Altuntas, I. \& Ozcelik, N. (2004). Protective effect of caffeic acid phenethyl ester (CAPE) on lipid peroxidation and antioxidant enzymes in diabetic rat liver. J Biochem Mol Toxicol, Vol. 18, No. 4, pp. (234-238), 1095-6670 (Print)

Yokozawa, T. \& Dong, E. (1997). Influence of green tea and its three major components upon low-density lipoprotein oxidation. Exp Toxicol Pathol, Vol. 49, No. 5, (Dec), pp. (329335), 0940-2993 (Print)

Yoon, J. H. \& Baek, S. J. (2005). Molecular targets of dietary polyphenols with antiinflammatory properties. Yonsei Med J, Vol. 46, No. 5, (Oct 31), pp. (585-596), 05135796 (Print)

Youn, H. S., Lee, J. Y., Fitzgerald, K. A., Young, H. A., Akira, S. \& Hwang, D. H. (2005). Specific inhibition of MyD88-independent signaling pathways of TLR3 and TLR4 by resveratrol: molecular targets are TBK1 and RIP1 in TRIF complex. J Immunol, Vol. 175, No. 5, (Sep 1), pp. (3339-3346), 0022-1767 (Print)

Youn, H. S., Lee, J. Y., Saitoh, S. I., Miyake, K., Kang, K. W., Choi, Y. J. \& Hwang, D. H. (2006). Suppression of MyD88- and TRIF-dependent signaling pathways of Tolllike receptor by (-)-epigallocatechin-3-gallate, a polyphenol component of green tea. Biochem Pharmacol, Vol. 72, No. 7, (Sep 28), pp. (850-859), 0006-2952 (Print)

Yun, H. J., Yoo, W. H., Han, M. K., Lee, Y. R., Kim, J. S. \& Lee, S. I. (2008). Epigallocatechin3-gallate suppresses TNF-alpha -induced production of MMP-1 and -3 in rheumatoid arthritis synovial fibroblasts. Rheumatol Int, Vol. 29, No. 1, (Nov), pp. (23-29), 0172-8172 (Print)

Zern, T. L. \& Fernandez, M. L. (2005). Cardioprotective effects of dietary polyphenols. J Nutr, Vol. 135, No. 10, (Oct), pp. (2291-2294), 0022-3166 (Print)

Zhang, M., Deng, C., Zheng, J., Xia, J. \& Sheng, D. (2006). Curcumin inhibits trinitrobenzene sulphonic acid-induced colitis in rats by activation of peroxisome proliferatoractivated receptor gamma. Int Immunopharmacol, Vol. 6, No. 8, (Aug), pp. (12331242), 1567-5769 (Print)

Zhao, Q., Wang, X., Nelin, L. D., Yao, Y., Matta, R., Manson, M. E., Baliga, R. S., Meng, X., Smith, C. V., Bauer, J. A., Chang, C. H. \& Liu, Y. (2006). MAP kinase phosphatase 1 controls innate immune responses and suppresses endotoxic shock. J Exp Med, Vol. 203, No. 1, (Jan 23), pp. (131-140), 0022-1007 (Print)

Zhong, M., Cheng, G. F., Wang, W. J., Guo, Y., Zhu, X. Y. \& Zhang, J. T. (1999). Inhibitory effect of resveratrol on interleukin 6 release by stimulated peritoneal macrophages of mice. Phytomedicine, Vol. 6, No. 2, (May), pp. (79-84), 0944-7113 (Print) 


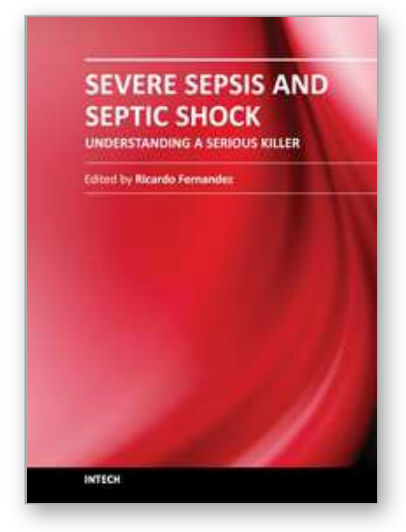

\author{
Severe Sepsis and Septic Shock - Understanding a Serious Killer \\ Edited by Dr Ricardo Fernandez
}

ISBN 978-953-307-950-9

Hard cover, 436 pages

Publisher InTech

Published online 10, February, 2012

Published in print edition February, 2012

Despite recent advances in the management of severe sepsis and septic shock, this condition continues to be the leading cause of death worldwide. Some experts usually consider sepsis as one of the most challenging syndromes because of its multiple presentations and the variety of its complications. Various investigators from all over the world got their chance in this book to provide important information regarding this deadly disease. We hope that the efforts of these investigators will result in a useful way to continue with intense work and interest for the care of our patients.

\title{
How to reference
}

In order to correctly reference this scholarly work, feel free to copy and paste the following:

Balázs Veres (2012). Anti-Inflammatory Role of Natural Polyphenols and Their Degradation Products, Severe Sepsis and Septic Shock - Understanding a Serious Killer, Dr Ricardo Fernandez (Ed.), ISBN: 978-953-307950-9, InTech, Available from: http://www.intechopen.com/books/severe-sepsis-and-septic-shockunderstanding-a-serious-killer/anti-inflammatory-role-of-natural-polyphenolic-compounds

\section{INTECH}

open science | open minds

\section{InTech Europe}

University Campus STeP Ri

Slavka Krautzeka 83/A

51000 Rijeka, Croatia

Phone: +385 (51) 770447

Fax: +385 (51) 686166

www.intechopen.com

\section{InTech China}

Unit 405, Office Block, Hotel Equatorial Shanghai

No.65, Yan An Road (West), Shanghai, 200040, China

中国上海市延安西路 65 号上海国际贵都大饭店办公楼 405 单元

Phone: +86-21-62489820

Fax: +86-21-62489821 
(C) 2012 The Author(s). Licensee IntechOpen. This is an open access article distributed under the terms of the Creative Commons Attribution 3.0 License, which permits unrestricted use, distribution, and reproduction in any medium, provided the original work is properly cited. 